$1-1-1971$

\title{
Alternative farm plans for eastern West Virginia livestock farms
}

\author{
Ronald A. Layton \\ Paul E. Nesselroad
}

Follow this and additional works at: https://researchrepository.wvu.edu/ wv_agricultural_and_forestry_experiment_station_bulletins

\section{Digital Commons Citation}

Layton, Ronald A. and Nesselroad, Paul E., "Alternative farm plans for eastern West Virginia livestock farms" (1971). West Virginia Agricultural and Forestry Experiment Station Bulletins. 597T.

https://researchrepository.wvu.edu/wv_agricultural_and_forestry_experiment_station_bulletins/700 @ WVU. It has been accepted for inclusion in West Virginia Agricultural and Forestry Experiment Station Bulletins by an authorized administrator of The Research Repository @ WVU. For more information, please contact ian.harmon@mail.wvu.edu. 


\section{Alternative Farm Plans for Eastern West Virginia Livestock Farms \\ Bulletin 597T

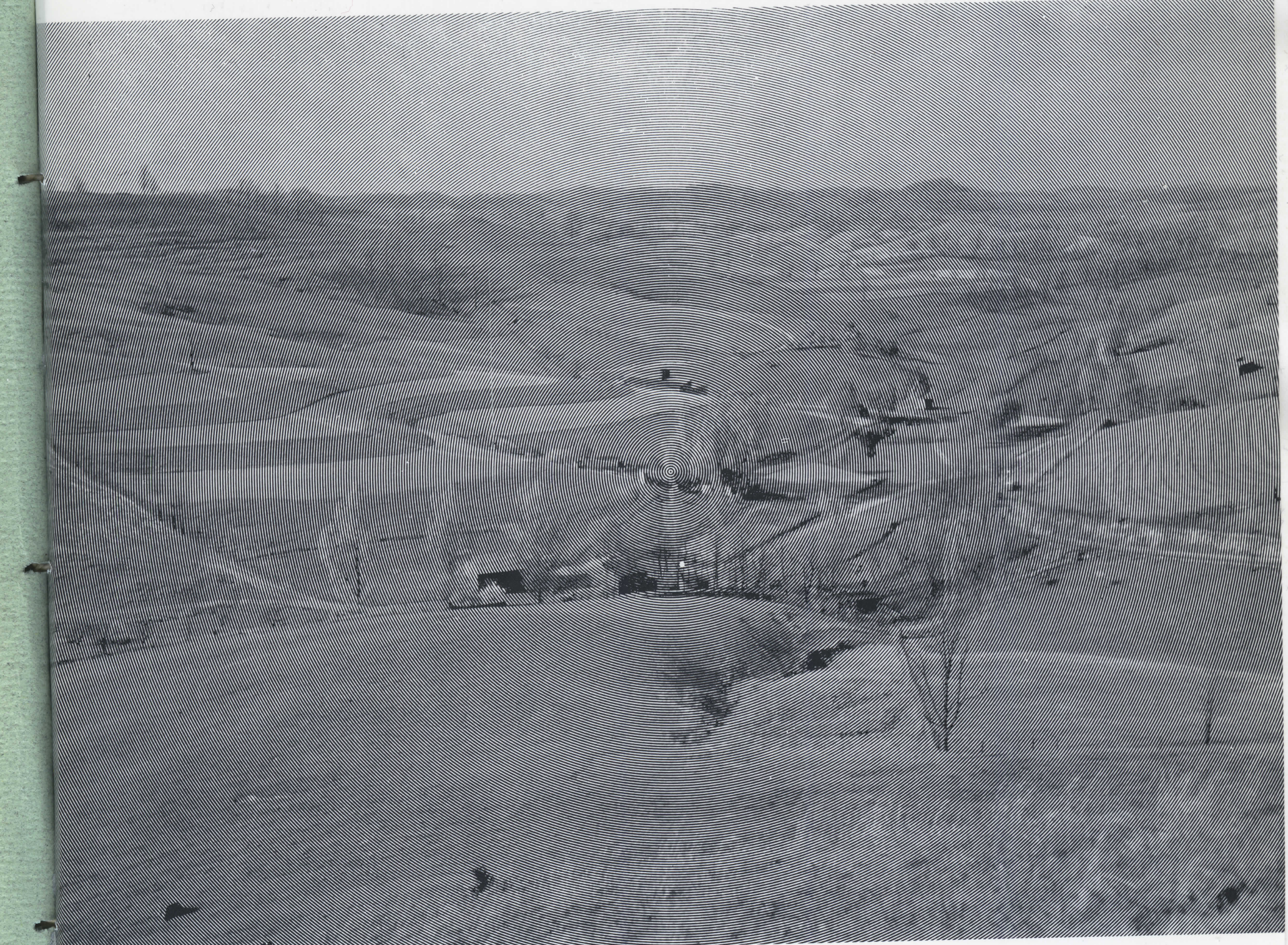

WEST VIRGINIA UNIVERSITY AGRICULTURAL EXPERIMENT STATION 


\section{SUMMARY}

The major objective of this study was to determine the most profitable combinations and levels of alternative livestock and cropping activities on eastern West Virginia farms that are currently engaged in beef cow-calf operations. These analyses were made using a "static," "short-run" economic setting and employing a conventional linear programming model.

The Study Region included the eight counties near the eastern border of West Virginia arrayed from Hampshire in the north to Monroe in the south. The Study Region was divided into three separate areas for purposes of this study. To reflect possible income differences associated with farm size, a "large" and a "small" benchmark farm were programmed in each of the study areas.

Alternative annual budgets of resources used, costs, production, and returns were estimated for beef, sheep, swine, dairy, grain, and forage enterprises. The budgets were developed to reflect above average management, and for the crop alternatives, yield differences due to climate, topography, and land-use ca- pability were incorporated.

The analyses indicated that the varying input-output relationships for crops existing between the three study areas and the levels of available resources for different farm sizes within the study areas affect the level of net returns to fixed factors for the selected group of study farms. However, the selected crop and livestock alternatives considered showed a consistent pattern of appearing in the optimum plans obtained and in the relative profitability of resource utilization for each of the study farms analyzed.

The analyses indicated that of the selected livestock alternatives considered, the most to the least profitable alternative uses for available resources on the study farms would be: (1) dairy, (2) market hogs, (3) sheep, (4) beef and other of the selected alternatives. The study also indicated that the present utilization of the available resources on the study farms for beef cow-calf production is not as profitable as dairy, market hog, and/or sheep production would be on these farms.

\section{THE AUTHORS}

At the time of this study, Ronald A. Layton was a Graduate Assistant in Agricultural Economics; Paul E. Nesselroad is Associate Agricultural Economist; and Alfred L. Barr, formerly an Agricultural Economist, is now Director, Division of Animal and Veterinary Sciences.

West Virginia University

Agricultural Experiment Station

College of Agriculture and Forestry

A. H. VanLandingham, Director

Morgantown 


\title{
ALTERNATIVE FARM PLANS FOR EASTERN WEST VIRGINIA LIVESTOCK FARMS
}

\author{
RONALD A. LAYTON, PAUL E. NESSELROAD, and ALFRED L. BARR
}

Adjustments in farm organization are of utmost importance when farm input costs increase significantly, livestock and crop prices received by farmers remain relatively unchanged, and technological innovation is rapid. This has been the situation confronting the American farmer in recent years. ${ }^{1}$ The farmer, to remain a competitive producer under these conditions, must rely on accurate economic analyses to provide the basis for the needed adjustment decisions. Only then will the farmer be assured that the resulting farm plans are the most profitable and consistent with the efficient use of available resources.

Barr, Toben, and Wilson recently completed a study of the resources, production, and income of 101 eastern West Virginia beef cattle farms on which the operators were considered to be above average managers of their beef enterprises. ${ }^{2}$ The farms studied averaged 555 acres with 124 acres being cropland and with open pasture constituting the remaining 431 acres. By assuming the same cropping enterprises and production performance levels of these farms in 196364 , and using average prices for 1955-64, they determined that by shifting to a beef cow-calf system, a herd averaging 109 brood cows could have been maintained yielding returns to labor, management, and investment of $\$ 2,338$. This would have been a 2.12 per cent annual return on the estimated investment of $\$ 109,981$ without a charge for labor or management. ${ }^{3}$ It is quite an understatement, but an important one, that this is a low return.

Adjustments appear necessary if these farmers are to realize an adequate labor and management income and higher return on their investment. One problem that such farmers are confronted with is difficulty in determining the combination of alternative livestock and cropping activities that will return the greatest profit, considering their resource constraints. Thus, an economic analysis, determining the most profitable use of available farm resources for selected enterprise alternatives, may provide a guideline to these eastern West Virginia farmers and to others to initiate change and to increase their farm incomes.

Aconomic Research, Statistical ${ }^{1}$ U. S. Department of Agriculture, Foreign Agricultural Services, Reporting, Agricultural Research, 1968 , Agricultural Handbook No. Handbook of Agricultural Chernment Printing Office, 1968), Figures 359 .

andson, Jr., ${ }^{2}$ Alfred L. Barr, George E. Toben, and Charles Cirginia Beef Resources, Production, and Incomersity Agricultural Experiment station Bulletin 546 (Morgantown: West Virginia University, 1967), p. 5.

3Ibid., p. 42.

\section{PURPOSE OF THE STUDY}

The major objective of this study was to ascertain the optimum combination and levels of selected livetock and cropping activities which would allow for maximum profit on eastern West Virginia farms currently engaged in beef cow-calf operations. This study was made with the assumption that prices and costs remained unchanged, and considering the basic kinds of resources available on these farms.

The special objectives of this study were to:

1. Update and improve the existing input-output data available for alternative livestock and cropping enterprises for farms in this region.

2. Ascertain knowledge of the more restrictive resource (s) for these farms.

3. Determine the optimum combinations of enterprises for maximum profit when the only livestock alternatives considered were beef, sheep, and swine.

4. Determine the effect on net farm income of the inclusion of a dairy enterprise as a feasible alternative.

\section{DESCRIPTION OF THE STUDY REGION}

The Study Region included the eight counties along or near the eastern border of West Virginia arrayed from Hampshire in the north to Monroe County in the south (Figure 1). The Region studied was identical to that of Barr, Toben, and Wilson. ${ }^{4}$ The physical features of the Region studied were described by these authors in their bulletin.

Due to differences in elevation, topography, climate, and land-use capability, the Study Region was divided into three study areas. They were: Study Area $\mathrm{I}$, including the northern counties of Hampshire, Hardy, Grant, and Pendleton; Study Area II, composed of Randolph and Pocahontas counties; and Study Area III, consisting of Greenbrier and Monroe counties in the southern portion of the Study Region.

\section{LIVESTOCK}

The Study Region, as is true of most of West Virginia, has considerable acreage of land suited to pasture and forage production. Thus, a grazing system of farming has evolved with the pasture and forage production being utilized by forage-consuming livestock - beef, sheep, and dairy animals. ${ }^{5}$

${ }^{4}$ Ibid., p. 10.

5Ibid., pp. 10-15. 


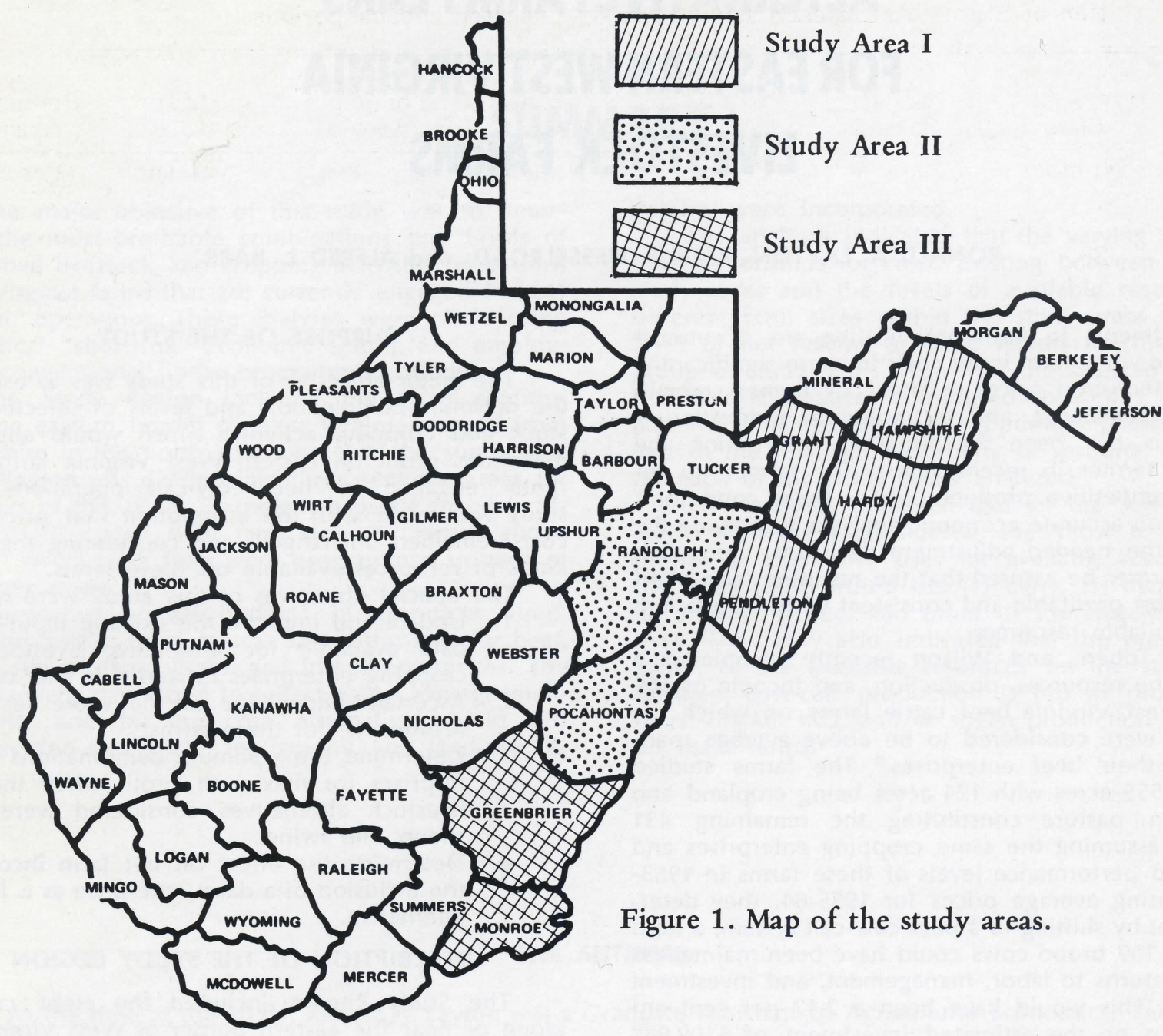

The 1930-64 trends of numbers of selected livestock classes are presented in Table 1 for both the State and each of the three study areas. The number in the livestock classes considered have decreased from 1930 to 1964 with the exception of beef cows for the State and for the three study areas combined; hogs have also increased in number in Study Area II.

Sheep have been the only class of livestock in the State to show a continual decrease in numbers throughout the period of 1930 to 1964 . However, during the same period, the relative proportion of the State's total sheep increased in each of the study areas.

\section{METHOD OF ANALYSIS}

The resources available on the selected sample of farms were determined by field surveys conducted in 1963-64. ${ }^{6}$ Production estimates and input requirements for livestock and cropping enterprises were obtained from: (1) published research data; (2) estimates of qualified, experienced agricultural scientists; (3) re- search results from experimental work; and (4) surveys of farmer experiences. ${ }^{7}$

Livestock and crop prices were based on the longterm seasonal average prices received by West Virginia farmers. Current (1969) retail prices were used for production goods and services, and were obtained by interviews with existing input suppliers of goods and services to West Virginia farmers.

Using these data, enterprise budgets were developed for beef, sheep, swine, dairy, grain, and forage alternatives. The budgets developed included the annual resource requirements, costs, production, and returns for a specified unit size. The enterprise inputoutput relationships were incorporated into a matrix table. Each column of the table represented the per unit specifications for each enterprise considered feasible and/or served as a disposal column for unused resources. The table rows were the simultaneous

${ }^{7}$ Ronald A. Layton, Alfred L., Barr, and Paul E. Nesselroad, Estimated Annual Costs, Production, and Income for Selected Livestock and Crop Enterprises, Eastern West Virginia, West Virginia University Agricultural Experiment Station Bulletin 594T (Morgantown, West Virginia, 1970). The input-output data, assumptions, procedures, and supporting data, plus documentation of sources for this study are presented in Bulletin 594T 
TABLE 1. Numbers of livestock, other than poultry, in West Virginia and three study areas, and portion of State total in each study area, by selected census periods.

\begin{tabular}{|c|c|c|c|c|c|c|c|}
\hline Year & State & $\begin{array}{l}\text { Study } \\
\text { Area I }\end{array}$ & $\begin{array}{l}\text { Portion in } \\
\text { Area I }\end{array}$ & $\begin{array}{l}\text { Study } \\
\text { Area II }\end{array}$ & $\begin{array}{l}\text { Portion in } \\
\text { Area II }\end{array}$ & $\begin{array}{l}\text { Study } \\
\text { Area III }\end{array}$ & $\begin{array}{c}\text { Portion in } \\
\text { Area III }\end{array}$ \\
\hline & Number & Number & Per cent & Number & Per cent & Number & Per cent \\
\hline \multicolumn{8}{|c|}{ BEEF COWS } \\
\hline $\begin{array}{l}1930 \\
1940\end{array}$ & 28,605 & 3,580 & 12.5 & 3,392 & 11.9 & 1,987 & 7.0 \\
\hline 1950 & 35,958 & $\begin{array}{r}4,901 \\
\end{array}$ & 13.6 & 4,996 & 13.9 & 2,175 & $\begin{array}{l}6.1 \\
74\end{array}$ \\
\hline 1959 & $\begin{array}{r}82,667 \\
141,864\end{array}$ & 13,185 & 16.0 & 7,333 & 8.9 & & $\begin{array}{l}7.4 \\
9.1\end{array}$ \\
\hline 1964 & $\begin{array}{l}141,864 \\
180,632\end{array}$ & $\begin{array}{l}22,605 \\
27,930\end{array}$ & $\begin{array}{l}15.9 \\
15.5\end{array}$ & $\begin{array}{r}9,131 \\
16,883\end{array}$ & $\begin{array}{l}6.4 \\
9.3\end{array}$ & $\begin{array}{r}12,963 \\
9,561\end{array}$ & $\begin{array}{l}9.1 \\
5.3\end{array}$ \\
\hline \multirow{2}{*}{\multicolumn{8}{|c|}{ MILK COWS ${ }^{a}$}} \\
\hline 1930 & 183,263 & 11,218 & 6.1 & 6,297 & 3.4 & 9,639 & \\
\hline 1940 & 218,769 & 11,918 & 5.4 & 8,083 & 3.7 & 12,177 & $\begin{array}{l}5.3 \\
5.6\end{array}$ \\
\hline 1950 & 203,997 & 13,038 & 6.4 & 8,287 & 4.1 & 16,240 & $\begin{array}{l}5.6 \\
8.0\end{array}$ \\
\hline 1959 & 121,151 & 8,492 & 7.0 & 5,078 & 4.2 & 10,946 & $\begin{array}{l}8.0 \\
9.0\end{array}$ \\
\hline 1964 & 83,895 & 8,752 & 10.4 & 5,154 & 6.1 & 2,934 & 3.5 \\
\hline \multicolumn{8}{|c|}{ SHEEP $^{b}$} \\
\hline 1930 & 567,747 & 79,021 & 13.7 & 64,239 & 11.1 & 56,520 & 9.8 \\
\hline 1940 & 437,381 & 67,472 & 15.4 & 47,169 & 10.8 & 50,690 & 11.6 \\
\hline 1950 & 421,700 & 95,875 & 22.7 & 52,969 & 12.6 & 54,780 & 13.0 \\
\hline 1959 & 290,449 & 89,729 & 30.2 & 41,442 & 14.3 & 38,771 & 13.4 \\
\hline 1964 & 194,932 & 47,000 & 24.1 & 39,297 & 20.2 & 32,943 & 16.9 \\
\hline \multicolumn{8}{|c|}{$\mathrm{HOGS}^{\mathrm{c}}$} \\
\hline 1930 & 221,681 & 22,420 & 10.1 & 8,075 & 3.6 & 14,981 & 6.8 \\
\hline 1940 & 171,765 & 19,323 & 11.3 & 6,778 & 4.0 & 10,037 & 5.8 \\
\hline 1950 & 197,286 & 28,894 & 14.7 & 8,457 & 4.3 & 14,453 & 7.3 \\
\hline 1959 & 148,238 & 31,100 & 21.0 & 5,386 & 3.6 & 11,384 & 7.7 \\
\hline 1964 & 77,971 & 15,298 & 19.6 & 9,841 & 12.6 & 2,849 & 2.7 \\
\hline
\end{tabular}

aBeef and dairy cows include cows and heifers two years of age and older.

bSheep numbers include "all sheep" except for years 1930 and 1940 with numbers used for "sheep older than three months and six months of age," respectively.

c"All hogs" were used except for 1940 for which only hogs at least four months old were used. Sources: U. S. Bureau of the Census, U. S. Census of Agriculture: 1930. Vol. II, Part 2, pp. 314, 338; 1940. Vol. I, Part 3, p. 240; 1950. Vol. I, Part 15, p. $390 ; 1959$. $1941,1952,1961,1966$ )

equations solved, considering resource constraints, to obtain optimum plans, except for a few rows being used strictly for accounting purposes. The simultaneous equations were solved employing a conventional linear programming computer program and the West Virginia University IBM 360/75 computer. $^{8}$

The linear programming technique is a mathematical procedure providing for the solution (maximization or minimization) of a linear function subject to a

The computer program employed was made available by $\mathrm{Dr}$ Paul Nericultural Economist, Division of Paul E. Nesselroad, Associate Aria University. set of limitations. ${ }^{9}$ The objective in solving the linear function for this study was to determine the cropping and livestock enterprise combinations which would maximize "net" income for given quantities of fixed resources.

Conventional linear programming analyses have the limitations of being static and normative. ${ }^{10}$ The

9For a linear programming procedures, see Earl O. Heady and Wilfred Cate College Press, 1958).

(o be

10 Normative refers to the plan or action which ought to be

taken; given the assumptions, cond 
time elapsing between the commitment of resources and the resulting output is ignored, and perfect knowledge of input-output relationships and of prices for inputs and products is assumed. Production in one period is not considered to affect production in subsequent periods. In addition, the optimum plan(s) income from production is attained only after a period of transformation from the existing farm programs. Consequently, the static analysis does not provide for consideration of the income flows during the transformation period or for long-run dynamic planning of the farm business.

\section{THE STUDY FARMS}

Information on the farms for this study was obtained from the same 101 farm records used in the earlier study by Barr, Toben, and Wilson. ${ }^{11}$ Fifty-one of the farms were located in Study Area I, twenty-three in Study Area II, and twenty-seven in Study Area III. Three visits were made during 1963 and 1964 to each farm to ascertain knowledge of the resources available and production levels achieved. Questionnaires completed during these visits provided information about the available resources on these farms.

\section{RESOURCE RESTRICTIONS FOR BENCHMARK FARMS}

In each of the study areas a "large" and a "small" farm were programmed to reflect possible income differences associated with farm size. Total cropland acreage was used as the index for arraying the sample farms in delineating the "large" and "small" farms for this study, as data were limited relative to other available resources.

Sample farms having equal to or greater than the median cropland acreage were grouped together and classified as "large size farms." The average (1) cropland acreage, (2) pasture acreage, (3) silo storage capacity, (4) livestock building space capacity, and (5) capital borrowing capability were estimated for these farms and considered to be the resources representative of the "large" size farm for each specific study area. Similarly, sample farms having less than or equal to the median cropland acreage were grouped together, and the above specified resources averaged to obtain the resource bases of the "small" size farm for each specific study area. The quantity of family labor available was also estimated for each representative "benchmark" farm. The resource availabilities determined for each "benchmark" farm are presented in Table $2 .^{12}$

\section{ALTERNATIVES CONSIDERED}

Livestock and cropping enterprise alternatives were budgeted for incorporation and utilization in the analysis. ${ }^{13}$ The input requirements, production esti-

\footnotetext{
${ }^{11}$ Alfred L. Barr, et al., op. cit.
}

12 For further information concerning the specifics of how the details of Table 2 were obtained, see Ronald A. Layton, "Optimum Farm Plans for Utilizing Resources by Selected Alternatives on Eastern West Virginia Livestock Farms," (Unpublished M.S. Thesis, Division of Resource Management, College of Agriculture and Forestry, West Virginia University, 1970), pp. 26-32.

${ }^{13}$ The budgets and additional supporting information are available as follows: Ronald A. Layton, et al., op. cit. mates, and price data utilized were ascertained to reflect above average management and differences in climate, topography, and land-use capability that would typically exist for the "benchmark" farms in the defined study areas.

The livestock enterprise alternatives considered were beef, sheep, dairy, and swine. A beef cow-calf enterprise was budgeted for two feed ration alternatives. Steer calves could either be retained from the beef cow-calf enterprise or purchased for utilization in a feeder steer wintering enterprise. Three winter rations were budgeted for the steers. The wintered steers could be retained, or similar steers purchased, for a summer pasturing period; this alternative is considered in the steer grazing enterprise budget.

Sheep budgets were developed in which the flock could be fed either of two rations. Sheep budgets were based upon one lamb crop per year. Five dairy cow enterprise alternatives were budgeted assuming a loose-housing system and rations emphasizing forage use. Five ration alternatives were budgeted ranging from one utilizing only forage to one with a ratio of one pound of grain per 4.75 pounds of milk. Assumed milk production responses ranged from 9,400 to 13,000 pounds. An initial herd size of 50 cows was assumed in constructing the dairy enterprise budgets. However, since the sample farms were selected on the basis of their present engagement in extensive farming programs, such as beef cow-calf, sheep, or both, the additional capital requirements for conversion to a dairy enterprise had to be determined in developing budgets for the dairy enterprise alternatives. Existing buildings on the "benchmark" farms were assumed to be adaptable for dairy feeding and loafing barns with paving and similar improvements. Consequently, the initial and annual costs of constructing and equipping a milk room and milking parlor to accommodate a 50-cow herd were estimated and incorporated as a capital requirement and cost for the dairy enterprise. The fixed labor required for the care and maintenance of the dairy herd of 50 cows was also determined. Once determined, the initial and annual costs for adapting existing farm buildings for feeding and loafing areas, providing a bulk tank and associated milking equipment, and the fixed labor requirement were prorated on a per cow basis for the budgets to be used in the programming analysis. To provide for expanding the herd above the initial 50-cow herd capacity, the total and annual costs per additional cow were estimated and incorporated as costs. To maintain the dairy herd, a budget for raising a dairy cow replacement was considered. ${ }^{14}$ An option of purchasing replacement heifers was also included in the analysis.

The buildings on these farms were also assumed readily adaptable to swine production. Two swine alternatives were considered. One was a sow-feeder pig enterprise with two alternative rations. The other swine alternative consisted of producing market hogs for sale in either February or July, or both, by retaining feeder

${ }_{14}$ Paul E. Nesselroad, Optimum Farm Organization for a Portion of the Appalachian Plateau, West Virginia University Agricultural Experiment Station Bulletin 593T (Morgantown: West Virginia University, June, 1970) Appendix Table 2. 
TABLE 2. Average resources available on "large" and "small" farms by Study Areas.

\begin{tabular}{|c|c|c|c|c|c|c|c|}
\hline \multirow[b]{2}{*}{ Resource } & \multirow[b]{2}{*}{ Unit } & \multicolumn{2}{|c|}{ Area I } & \multicolumn{2}{|c|}{ Area II } & \multicolumn{2}{|c|}{ Area III } \\
\hline & & $\begin{array}{l}\text { Large } \\
\text { Farm }\end{array}$ & $\begin{array}{l}\text { Small } \\
\text { Farm }\end{array}$ & $\begin{array}{l}\text { Large } \\
\text { Farm }\end{array}$ & $\begin{array}{c}\text { Small } \\
\text { Farm }\end{array}$ & $\begin{array}{c}\text { Large } \\
\text { Farm }\end{array}$ & $\begin{array}{l}\text { Smal } \\
\text { Farm }\end{array}$ \\
\hline
\end{tabular}

\begin{tabular}{|c|c|c|c|c|c|c|c|}
\hline \multicolumn{8}{|l|}{$\begin{array}{l}\text { Cropland } \\
\text { Bottomland }\end{array}$} \\
\hline $\begin{array}{l}\text { Bottomland } \\
\text { Class I }\end{array}$ & acres & 112 & 50 & 41 & 29 & 0 & $\begin{array}{l}0 \\
0\end{array}$ \\
\hline Class II & acres & 10 & 0 & 0 & 0 & 0 & $\begin{array}{l}0 \\
0\end{array}$ \\
\hline \multirow{2}{*}{\multicolumn{8}{|c|}{$\begin{array}{l}\text { Class III } \\
\text { Upland } \\
\text { Class II }\end{array}$}} \\
\hline & & & & & & & 30 \\
\hline Class II & acres & $\begin{array}{l}12 \\
32\end{array}$ & 8 & 2 & 7 & 49 & 12 \\
\hline Class III & acres & $\begin{array}{l}32 \\
10\end{array}$ & 7 & 24 & 6 & 47 & 11 \\
\hline $\begin{array}{l}\text { Class IV } \\
\text { Total cropland }\end{array}$ & acres & 176 & 81 & 181 & 75 & 164 & 53 \\
\hline \multirow{2}{*}{\multicolumn{8}{|c|}{$\begin{array}{l}\text { Total cropland } \\
\text { Pastureland } \\
\text { Bottomland }\end{array}$}} \\
\hline & & & & & & & \\
\hline Improvable & acres & 69 & $\begin{array}{r}49 \\
0\end{array}$ & 43 & 35 & 0 & 0 \\
\hline \multirow{2}{*}{\multicolumn{8}{|c|}{$\begin{array}{l}\text { Improvable } \\
\text { Unimprovable } \\
\text { Upland }\end{array}$}} \\
\hline & & 417 & 201 & 199 & & & 211 \\
\hline $\begin{array}{l}\text { Improvable } \\
\text { Unimprovable }\end{array}$ & acres & 113 & 68 & 312 & 188 & 55 & 39 \\
\hline $\begin{array}{l}\text { Unimprovable } \\
\text { Total pastureland }\end{array}$ & acres & 604 & 318 & 557 & 340 & 443 & 250 \\
\hline $\begin{array}{l}\text { Total pastureland } \\
\text { Total crop and pastureland }\end{array}$ & acres & 780 & 399 & 738 & 415 & 607 & 303 \\
\hline $\begin{array}{l}\text { Total crop and pastureland } \\
\text { Livestock building space }\end{array}$ & sq. feet & 10,700 & 4,700 & 7,800 & 4,000 & 6,800 & 4,200 \\
\hline Silo capacity & tons & 670 & 350 & 360 & 190 & 480 & 320 \\
\hline \multicolumn{8}{|l|}{$\begin{array}{l}\text { Silo capacity } \\
\text { Available family labor }\end{array}$} \\
\hline Winter (November 1-March 15) & hours & 1,295 & 1,295 & 1,295 & 1,295 & $\begin{array}{l}1,295 \\
1.090\end{array}$ & $\begin{array}{l}1,295 \\
1,090\end{array}$ \\
\hline Spring (March 16-June 30) & hours & 1,090 & 1,090 & 1,090 & 1,090 & $\begin{array}{r}1,090 \\
805\end{array}$ & $\begin{array}{r}1,090 \\
805\end{array}$ \\
\hline $\begin{array}{l}\text { Summer (July 1-August } 31 \text { ) } \\
\text { Fall (September } 1 \text {-October } 31 \text { ) }\end{array}$ & hours & 805 & 805 & 805 & 805 & $\begin{array}{l}805 \\
575\end{array}$ & $\begin{array}{l}805 \\
575\end{array}$ \\
\hline Fall (September 1-October 31) & hours & 575 & 575 & 575 & 575 & $\frac{575}{3,765}$ & $\frac{575}{3,765}$ \\
\hline Total annual family labor & $\begin{array}{l}\text { hours } \\
\text { dollars }\end{array}$ & $\begin{array}{r}3,765 \\
69,000\end{array}$ & $\begin{array}{r}\overline{3,765} \\
35,000\end{array}$ & $\begin{array}{r}, 765 \\
67,000\end{array}$ & $\begin{array}{r}3,765 \\
37,000\end{array}$ & $\begin{array}{r}3,700 \\
59,000\end{array}$ & $\begin{array}{r}5,100 \\
28,000\end{array}$ \\
\hline
\end{tabular}

Capital borrowing capacity

pigs from the sow-feeder pig enterprise, or by purchasing the required feeder pigs.

Corn, small grain, and hay alternatives were budgeted for the specific soils of the representative farms in each study area. Yields were estimated for an optimum fertilization level determined from field trial tests in locations in the study area. Fertilizer and lime applications for each of the cropland soils were estimated with the phosphorus, potassium, and calcium levels of each of the soils taken into consideration. Recommendations made to farmers by West Virginia University agronomic specialists for the specific soils were followed in determining the requirements. The yields of all forage crops were adjusted for dry-matter losses associated with the harvest, storage, and feeding of the crops. ${ }^{15}$

Grain crop budgets were developed for corn, oats, wheat, and barley. The small grain enterprises were budgeted both as grain and hay alternatives. The small

15. Agricultural Planning Data for the Northeastern United States,

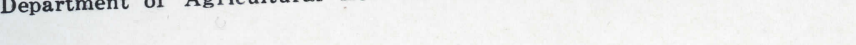

rain yields were reduced; they were assumed to serve as a companion crop in rotation when seeding for hay establishment.

Forage-producing alternatives were budgeted for cilage, clover, and orchardgrass. Clover production was budgeted assuming it was either grown alone for a two-year life-stand or in rotation with orchardto have a life-stand grass. Orchardgrass was estimated to filized as budgeted. of from one to ten years when fertized as buere al-

In the programming matrix table, crops wand to lowed to enter into rotation on each class of land by the degree of land-use intensification ${ }^{16}$ recommended conservation practices. ${ }^{16}$

The Pennsylvania State University, 1965), R.S. 51 Univer 45-46. Based on dry matter, clover hay yields were Table 30.4 per cent for harvesting, storing, and feeding yields were reduce clover-grass hay, orchardgrass hay, and corn cent, respectively. reduced by 27.3 per cent, 21.2 per cent, and 8.1 fed to livestock, yields In addition, if these hays were sold instead of reduced 24.5 per cent, of clover, clover-grass, and orchardgrass wely. In each case, the hays 21.0 per cent, and 14.4 per cent, respecthay conditioner, with no more were assumed to be field cured with a hayed on during the harvestthan 20 per cent of the hay crop ing process.

6The maximum class and soil were 
Budgets were developed for annual maintenance of pastures at three levels. ${ }^{17}$ The three levels considered were: One in which the pasture was fenced and remained, otherwise, in an unimproved state; a second in which the pasture was fenced, limed and fertilized periodically, and clipped annually; and a third alternative, the same as the second but with reseeding. The budgets reflected the lime and fertilizer requirements for pasture soils commonly found in the study areas, following the same procedure as was specified in determining the lime and fertilizer requirements of cropland soils. The pasture alternatives were budgeted for both upland and bottomland pastures.

The pasture budgets included the animal unit capacities of the different pastures for five grazing months divided into two pasturing periods, May-June and July-August-September. Most West Virginia pastures are characterized by greater pasture growth during the first period than in the summer months. No provisions were made for harvesting excess production during the first pasturing period. However, the option of allowing 50 per cent of any unused May-June capacity to be transferred for livestock pasturing during the July-September period was considered. ${ }^{18}$

Two alternative methods for financing pasture improvement were assumed available: (1) the farmer paying all the expenses and (2) the government paying 80 per cent of the seed costs and 50 per cent of the lime and fertilizer costs through ACP governmental programs. ${ }^{10}$

Budgets were prepared for the annual seeding of sudangrass for pasture for each of the cropland soils specified. The animal unit carrying capacities of these pastures were reduced 20 per cent to account for estimated losses due to livestock tramping and unpalatable stalks. ${ }^{20}$

The feeding of hay to supplement pastures during the July-September pasturing period was a permitted alternative. As such, an animal unit equivalent was estimated to require an average of 450 pounds of T.D.N. per month in this supplemental feeding alternative ${ }^{21}$

Governmental land retirement and diversion programs for corn, wheat, and barley were ignored in the analysis since only three of the 101 study farms indicated any established historical acreage allotment.

An adequate machinery complement was available for utilization in the cropping alternatives. Custom hir-

based on guidelines provided in U. S. Department of Agriculture, Soil Conservation Service, Soil Survey: Monroe County: Berkeley County: Tucker County, West Virginia (Washington: U. S. Governand 28-33.

17 Layton, et al., loc. cit.

18 These data were based on estimates by Dr. G. G. Pohlman Agronomist, Division of Plant Sciences, West Virginia University, with him using result of research efforts in this area.

Based on data obtained from Mr. Allen Miller of USDA, Agri列 cultural Stabilization and Conservation Servic

20Pohlman, loc. cit.

21Alfred L. Barr, et al., Beef Cattle Systems and Range Improvement Alternatives: Estimated Production, Income, and Costs, Oklahoma State University Agricultural Experiment Station Processed ing of field operations was not considered since little currently is known about the availability and existing rates for such services in West Virginia.

Other alternatives considered in the analysis were the buying and selling of grains, hays, straw, and pasture rental.

\section{PRICES USED}

Long-term seasonal average prices were used for each livestock class. ${ }^{22}$ Feeder calf prices used were those existing during the period 1960-68, with adjustments, using linear regression coefficients, made in prices for the heavier weights assumed as compared to the State average weights. Prices for spring yearling steers and fall prices for feeder and stocker cattle were based on prices received at the Winchester, Virginia, and Moorefield, West Virginia, markets, respectively, during the $1960-68$ period.

Sheep prices used were an average of those received during the period of $1960-68$ by a select group of farmers whose gross income per ewe was among the highest 20 per cent of the flocks recorded in the West Virginia Master Shepherd's Program.

Prices used for market hogs were based on Chicago prices for the period 1964-68. Statistical tests made by the authors on the means and variances of Chicago prices versus Moorefield, West Virginia market prices for this period indicated the price differentials between the two markets to be non-significant at the 0.01 probability of error level. Therefore, due to the availability of data, Chicago prices were used.

Milk prices used were the blend prices existing for markets in each of the study areas in 1968 with deductions made for marketing charges.

Prices used for determining crop receipts were an average of the prices received for crops by West Virginia farmers during the period 1959-67. The prices used for production goods and services were based on 1969 retail market quotations obtained from suppliers for West Virginia farmers.

\section{MEASURE OF PROFITABILITY - NET INCOME}

Net income was the criterion used in evaluating the relative profitability of the alternative farm plans. However, as used in this analysis "net income" was not the return above all costs. To approximate the true "net" return or profit, appropriate costs would need to be inputed and deducted from the "net income" figure determined for each farm plan, for such items as land rent, building and machinery investment (and/or depreciation), unpaid family labor, real estate taxes, management, and risk. However, these items were assumed fixed costs for the farm situations analyzed, since "net income" as used in the analvsis, was deemed entirely appropriate for comparing the relative profitability of utilizing the resources existing on the study farms in the production of a selected group of alternatives.

\section{SITUATIONS ANALYZED}

Five different situations were analyzed for each ${ }^{22}$ Layton, et al., loc. cit. 
size farm in each study area. However, the dairy alternatives were not considered in the first four situations analyzed, since the farmers in the sample indicated their future intentions to continue with extensive livestock programs (beef) as opposed to dairy. For Situation 1, all alternatives were considered. In Situation 2, consideration was made of all alternatives except the selling of hay and the renting-out of pasture. In Situation 3, all alternatives were considered except grain selling activities. In Situation 4, all alternatives were considered, and the market hog alternatives were limited to a maximum production of 125 head per period (February and/or July). Situation 5 consisted of all alternatives, including the dairy options.

To assess the effects of price variability for livestock products on the stability of the different optimum plans obtained, price mapping procedures were employed using appropriate and realistic price ranges for the alternative livestock products.

\section{RESULTS AND ANALYSIS}

The "basic" farm plans determined for each of the two farm sizes in each of the three study areas are presented in the following sections. Differences between the "basic" optimum plans and the optimum plans obtained when other options were considered are discussed.

Acceptance or rejection of the optimum plans must be based on several assumptions. First, the farmers would need to implement recommended fertilization and liming practices for their specific cropland soils and climatic conditions. Secondly, changing the present farm organizations to the optimum farm plans determined would be conditioned by the farmer's own capacity to acquire capital and willingness to risk the capital. Further, the individual farmer's managerial skill may or may not suffice for the optimum plans, and the farmer may have goals other than profit maximization in carrying on his farming program.

\section{"Basic" Optimum Farm Plans Obtained With All Alternatives Considered, Except Dairy}

The "basic" optimum farm plans determined when all alternatives except dairy were considered are shown in Table 3. In each of the Study Areas, size of business had a pronounced effect on net income with the "basic" optimum farm plans for the large farms yielding more than double the net income of the small farms (Table 3). The dollar differential associated with farm size was also considerable and consisted of $\$ 21,500, \$ 16,200$, and $\$ 14,500$ for Study Areas I, II, and III, respectively.

The "basic" optimum farm plans included February and July market hogs as the major livestock enterprise on each size farm analyzed. Production per market period consisted of 1,$137 ; 975$; and 818 head of hogs on the three large farms, and 575; 500; and 374 head on the three small farms in Study Areas I, II, and III, respectively (Table 3 ). The feeder pig requirements of the market hog operations were met entirely by purchase rather than by farm production.
The market hogs utilized all the corn grain produced on the farms' cropland acreage; a considerable quantity of corn grain had to be purchased to meet the total feed grain requirement of the hogs.

The only other livestock enterprise to be included in the "basic" optimum plans was sheep. A sheep enterprise was included in the "basic" optimum farm plans only when capital limitations were reached prior to limits on building space capacity. Since it was assumed a chattel asset would raise capital borrowing limits by a 2:1 asset-debt ratio, sheep, as chattel assets, added to the capital borrowing capacity and were complementary to hogs (non-chattel assets) until building space restricted the numbers of both livestock alternatives. Consequently, sheep enterprises were included in the "basic" farm plans for both the large and the small farms in Study Areas I and III, with flock sizes of 80 and 13 ewes on the large farms and 5 and 61 ewes on the small farms in the two Study Areas, respectively. However, building space, rather than capital, was the restricting resource for both farm sizes in Study Area II. Consequently, sheep were not a part of these plans. The sheep alternative for this "basic" option was one in which all animals were fed grain, and the flock wintered on clover-grass hay.

Total cropland was utilized in all "basic" farm plans, with cropland use strongly influenced by the limitations imposed on corn grain production. Class I bottomland, available only in Study Areas I and II, was used exclusively for continuous corn grain production. All Class II cropland, except for the small farm of Study Area III, was utilized in the most intensive or shortest rotation permitted: two years of corn grain, one year of small grain, and two years of clover hay. Class III cropland was utilized in a longer rotation that consisted of one year of corn grain, a year of small grain, two years of clover-grass hay, and three years of orchardgrass hay. Utilization of Class IV cropland was similar to that of Class III cropland except for corn which had not been permitted in the rotation considered. The optimum plan for the small farm in Study Area III differed from all other "basic" optimum plans in cropland utilization, primarily because cropland availability was the most limited of all "basic" farm situations programmed. This farm plan included extensive rotations on all classes of cropland (Classes II, III, and IV), and was the only farm plan to include the most extensive rotation permitted consisting of orchardgrass hay for a 10-year life-stand on the Class IV cropland.

Wheat for grain was consistently included as the small grain in rotation on all classes of cropland. The exception to this was for the small farm optimum plan in Study Area II in which oat grain was included in the rotation for Class III bottomland and Class II upland cropland. This was due to high yields of oats per acre for this particular study area, and surplus family spring labor being available. Conversely, the large farm plans that included hiring additional spring labor did not produce spring oats as it was unprofitable to hire spring labor for small grain production.

The small farm plan of Study Area III included producing a small acreage ( 0.6 acre) of oats for grain 
TABLE 3. "Basic" optimum plans obtained with all alternatives considered, except dairy, for two farm sizes in each of three study areas.

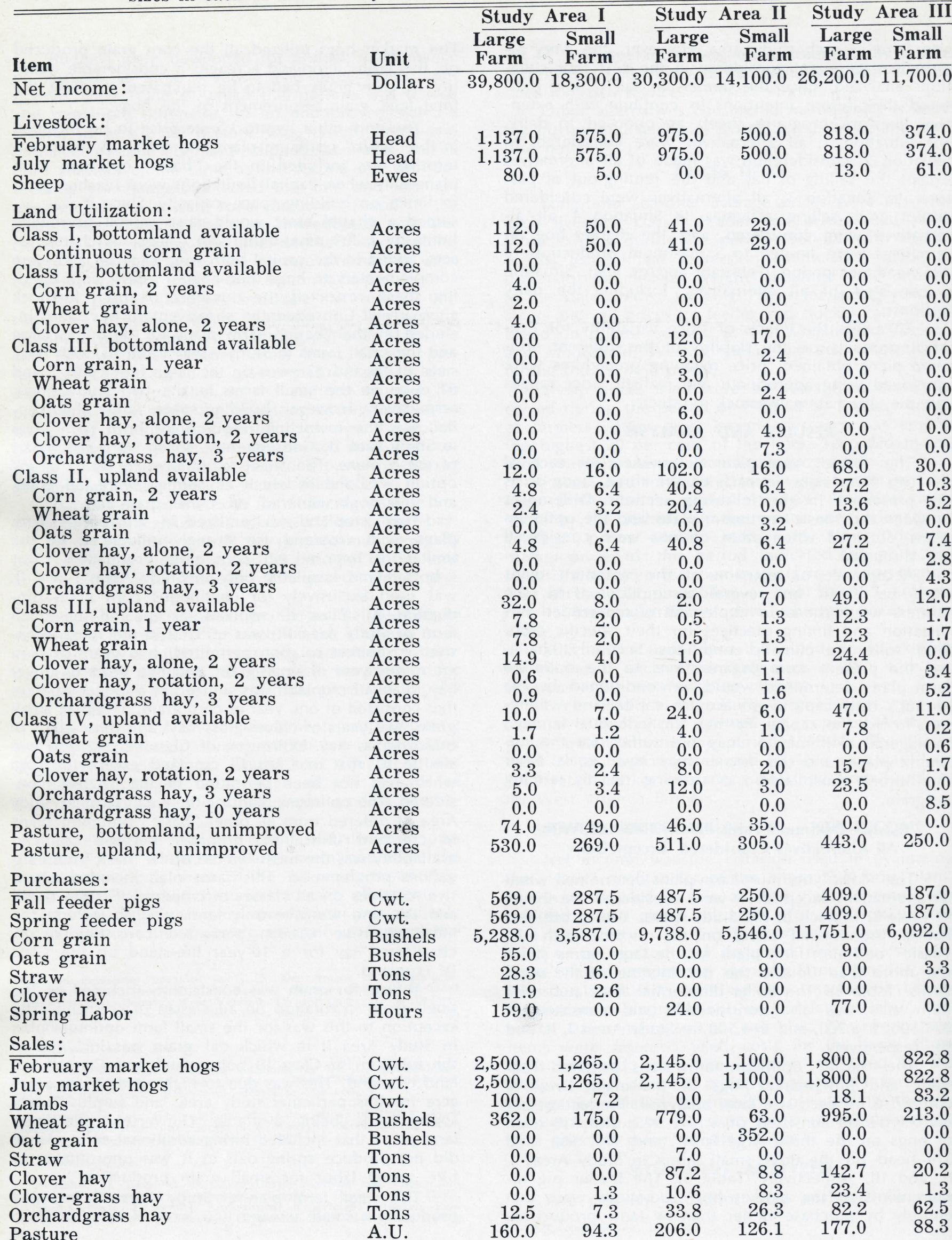

Other:

Operating capital

Investment capital

Total capital

Transfer pasture

ACP funds used for hayland
Dollars

Dollars

Dollars

A.U.

Dollars $\begin{array}{llllll}68,100.0 & 34,900.0 & 64,300.0 & 33,200.0 & 58,900.0 & 27,300.0\end{array}$

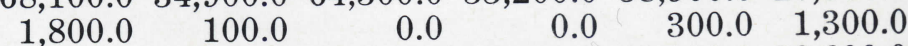
$\begin{array}{lllllll}69,900.0 & 35,000.0 & 64,300.0 & 33,200.0 & 59,200.0 & 28,600.0\end{array}$

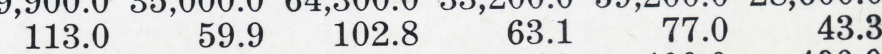
$\begin{array}{llllll}170.0 & 101.0 & 400.0 & 400.0 & 400.0 & 400.0\end{array}$ 
on Class IV upland as feed for the sheep enterprise. However, oats were purchased rather than raised for sheep feeding in the large farm plans in Study Areas I and III.

Small grain, mixed clover-grass hay, and/or orchardgrass hay sales were common to all "basic" optimum farm plans. However, to meet the total nutritional requirements of the market hogs, some clover hay had to be purchased in the optimum plans for both farm sizes in Study Area I.

All pastureland utilized was unimproved pasture. Except for minor quantities of pastureland required by plans containing sheep, all pastureland was rentedout. The transfer of surplus spring pasture capacity for summer pasture utilization was also common to the "basic" farm plans.

Available ACP funds (\$400) were completely utilized for hay establishment and maintenance for all farm plans in Study Areas II and III. However, more than half of the ACP funds were left unused in both farm plans of Study Area I, since most of the cropland acreage was utilized in a rotation that did not meet the minimum ACP requirement that hay be in rotation for three or more consecutive years, and all pastureland utilized was unimproved.

Total capital requirements varied considerably for the "basic" optimum farm plans, especially between the optimum plans for the large and the small farms. In each Study Area the large farm plans required about twice as much total capital for their operation as did the small farm plans, which was not unexpected since the large farm resource availabilities were generally double those of the small farms, except for labor (Table 2). Considering that both the labor availability and utilization were nearly constant regardless of farm size, since the large farms' net incomes were double those of the small farms, the return per hour of labor for operating the large farm businesses was also double.

\section{Value of the Marginal Products Restrictive Resources} in the "Basic" Optimum Plans

The Value of the Marginal Products (VMP's) of a resource is the amount by which net income would be increased by utilization of an additional unit of the resource, for example, an acre of land, an hour of labor or a dollar of capital. Therefore, the VMP is the maximum price that can profitably be paid for another unit of a restrictive resource, since if an available resource is not completely used (or restrictive) in a farm plan, the VMP for this surplus resource is zero.

Capital was a restrictive resource in the basic plans for both farm sizes in Study Areas I and III (Table 3). The VMP's were 16 per cent for operating capital and 15 per cent for investment capital (Table 4). Thus, additional capital could have been profitably used, if available, for less than these interest rates.

Livestock building space was a restrictive resource for all farm plans (Table 4). For the plans in Study Areas I, II, and III, respectively, the large farms had $V_{M P}$ 's per square foot of building space of $\$ .90, \$ 1.71$ and $\$ 0.95$ and the small farms, \$1.06, \$1.76, and \$1.06.
The VMP's for both Study Area II optimum plans (ones with no sheep) were $\$ 0.76$ on the large farm and $\$ 0.70$ on the small farm per square foot higher for building space than the other optimum plans having sheep, due to the greater profitability of market hogs compared to sheep.

Cropland was restrictive for all "basic" farm plans. The VMP's for cropland used intensively for corn grain were high, ranging from approximately $\$ 171$ per acre (Table 4). These VMP's for cropland further indicate the relative profitability of crop production on these farms. Even when capital became restrictive for the basic plans having sheep it was more profitable to continue cropping the land and to substitute sheep for hogs to acquire additional capital borrowing capacity.

Spring labor was a restrictive resource for all large farm "basic" plans. The VMP's for spring labor were $\$ 1.28$ per hour for the large farms in Study Areas I and III and \$1.19 per hour for the large farm in Study Area II. Consequently, hiring additional spring labor at the rate of $\$ 1.10$ per hour would have been profitable had more building space and/or capital been available.

Market hog production appeared to provide the most profitable resource utilization on the study farms for the selected livestock alternatives considered in the "basic" option. Sheep were second in the profitability order for this option and entered the optimum plans when capital became restrictive for market hog producNo beef cattle alternatives appeared in the "basic" optimum plans. Crop rotations for these optimum plans were intensive (short duration), emphasizing corn grain production profitability. In genral cropland utilization was quite profitable in that market hog production was reduced, instead of crop ren capital became restrictive. Further, small grains and sizeable quantities of hay produced, when not utilized by livestock, were sold.

\section{Optimum Farm Plans with Dairy and the Selling of Hay And Pasture Excluded}

The optimum farm plans determined when the dairy alternatives and the alternatives of selling hay and renting-out pastureland were eliminated from consideration are presented in Table 5. As Table 5 shows, net incomes yielded from these plans varied considerably both between Study Areas and between farm size. Only minor decreases occurred in the net income values for these optimum plans in Study Area I as compared to the "basic" plans. However, the net income values decreased to levels of $\$ 25,900$ and $\$ 18,400$ for the optimum plans of the large farms and $\$ 12,900$ and $\$ 9,600$ for the optimum plans of small farms in Study Areas II and III, respectively.

As in the optimum plans for the "basic" options (Table 3), the net income for the large farm was about twice that for the small farm in each Study Area. In addition, the net income for both farm sizes in Area I was nearly twice that of the Study Area III, and about 50 per cent greater than the respective farm sizes in Area II.

Market hogs remained as the major livestock enterprise and at nearly the same numbers as in the 
"basic" optimum plans (Table 5). Sheep also appeared in the optimum plans at nearly the same numbers as before, and capital requirements changed very little compared to the "basic" plans.

The major change between these optimum plans and the "basic" optimum plans occurred in the use of cropland. Class I cropland continued to be utilized for continuous corn grain production. Corn grain was also purchased in large quantities to meet market hog feed requirements. Classes II and III cropland was utilized in the most intensive rotation permissible (no more than two years of clover hay production). Utilization of Class IV cropland in Study Area I was similar to its use in the "basic" plans, but this class of cropland was unused in all optimum plans in the other study areas.

Some of the clover hay produced in these optimum plans was utilized by both the market hog and sheep enterprises, with the clover hay used for pasture supplementation for sheep. Clover hay production in the optimum plans for Study Areas II and III went unused, as a hay crop was required in rotation with the corn and small grain enterprises included in the plans, indicating the relative profitability of corn and small grain production. Prohibiting the sale of hay greatly reduced the net income values for those farm plans that were more restricted in acreages of cropland that could be intensively utilized for corn grain production.

Although more oats grain production was included in these optimum plans than in the "basic" plans, spring labor availability for small grain production was not fully utilized except in the large farm plan of Study Area I. In both farm plans for Study Area I, oats were purchased rather than raised for sheep. All farm plans included wheat sales and the plans of Study Area II and III included oats sales.

Only those plans having sheep utilized any pastureland, and this was unimproved pasture. Since renting-out of pasture was not permitted in these plans, sizeable acreages of pastureland for all farms were unused. ACP funds were completely unused since no pasture was improved and no hay rotation established for three or more consecutive years.

In the optimum plans of Study Area I all Class IV cropland was utilized and hence was restrictive for these farm plans. Class IV cropland went unused in the other optimum plans (or had no value). Class IV cropland had a VMP of approximately $\$ 40$ per acre for the large farm, and a VMP of only $\$ 0.20$ or approaching

TABLE 4. Value of the marginal products (VMP's) for restrictive resources for "b a s i c" optimum plans for two farm sizes in each of the three study areas.

\begin{tabular}{|c|c|c|c|c|c|c|c|}
\hline & & Study & Area I & Study & Area II & Study & Area III \\
\hline Item & Unit & $\begin{array}{l}\text { Large } \\
\text { Farm }\end{array}$ & $\begin{array}{l}\text { Small } \\
\text { Farm }\end{array}$ & $\begin{array}{l}\text { Large } \\
\text { Farm }\end{array}$ & $\begin{array}{l}\text { Small } \\
\text { Farm }\end{array}$ & $\begin{array}{l}\text { Large } \\
\text { Farm }\end{array}$ & $\begin{array}{l}\text { Small } \\
\text { Farm }\end{array}$ \\
\hline Cropland: & & & & & & & \\
\hline$\overline{\text { Class I, bottomland }}$ & Acres & $\$ 168.03$ & $\$ 171.24$ & $\$ 127.67$ & $\$ 125.06$ & - & - \\
\hline Class II, bottomland & Acres & 87.32 & - & - & - & - & - \\
\hline Class III, bottomland & Acres & - & - & 49.51 & 60.65 & - & - \\
\hline Class II, upland & Acres & 79.14 & 83.25 & 81.79 & 87.02 & $\$ 92.42$ & $\$ 98.27$ \\
\hline Class III, upland & Acres & 60.78 & 62.26 & 65.71 & 70.93 & 75.62 & 88.95 \\
\hline Class IV, upland & Acres & 50.69 & 55.37 & 56.89 & 70.54 & 61.38 & 81.30 \\
\hline Pastureland: & & & & & & & \\
\hline Bottomland & Acres & 0.54 & 0.54 & 0.58 & 0.58 & - & - \\
\hline Upland & Acres & 0.05 & 0.05 & 0.32 & 0.32 & 0.34 & 1.06 \\
\hline Livestock building space: & Sq. ft. & 0.90 & 1.06 & 1.71 & 1.76 & 0.95 & 1.06 \\
\hline Silo capacity: & Ton & N.R. ${ }^{a}$ & N.R. & N.R. & N.R. & N.R. & N.R. \\
\hline Labor: & & & & & & & \\
\hline Winter & Hour & N.R. & N.R. & N.R. & N.R. & N.R. & N.R. \\
\hline Spring & Hour & 1.28 & N.R. & 1.19 & N.R. & 1.28 & N.R. \\
\hline Summer & Hour & N.R. & N.R. & N.R. & N.R. & N.R. & N.R. \\
\hline Fall & Hour & N.R. & N.R. & N.R. & N.R. & N.R. & N.R. \\
\hline Capital: & & & & & & & \\
\hline Operating & Dollar & 0.16 & 0.16 & N.R. & N.R. & 0.16 & 0.16 \\
\hline Investment & Dollar & 0.15 & 0.15 & N.R. & N.R. & 0.15 & 0.15 \\
\hline
\end{tabular}

a"N.R." represents "not restrictive." This implies that quantities of the resource were unused and that additional units would have zero value for the farm plan. 
TABLE 5. Optimum farm plans obtained with all alternatives considered, except dairy and selling of

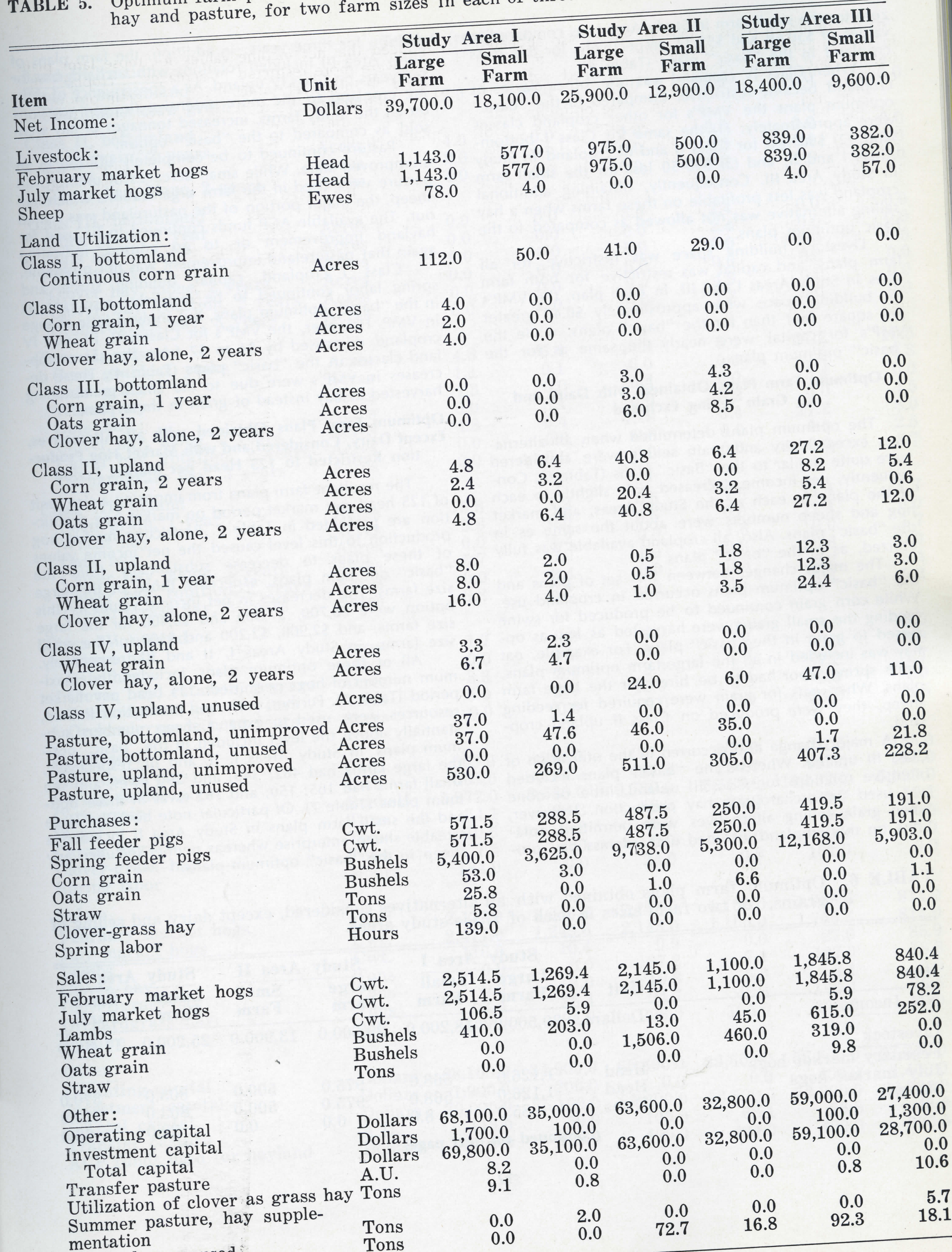


zero for the small farm in Study Area I, as compared to values of $\$ 50.69$ and $\$ 55.37$, respectively, for this class cropland in the "basic" plans (Table 4).

When Class IV cropland was idle, other classes of cropland became restrictive. Compared to the "basic" optimum plans the VMP's for other cropland classes were approximately: (1) the same for Class I bottomland, (2) \$30 less for Class II and III cropland in Study Areas I and II, and (3) $\$ 40-50$ less for the small farm in Study Area III. Consequently, obtaining additional cropland was less profitable on these farms when a hay selling alternative was not allowed as compared to the basic optimum plans.

Livestock building space was restrictive for all farm plans, and capital was restrictive for both farm sizes in Study Areas I and III. In each plan, the VMP's for building space were approximately $\$ 0.40$ greater per square foot than for the "basic" plans, while the VMP's for capital were nearly the same as for the "basic" optimum plans.

\section{Optimum Farm Plans Obtained with Dairy and Grain Selling Excluded}

The optimum plans determined when all alternatives except dairy and grain selling were considered were quite similar to the "Basic" plans (Table 6). Consequently, net income decreased only slightly in each of the plans in each of the Study Areas, and market hog and sheep numbers were about the same as in the "basic" plans. Also, all cropland available was fully utilized, as in the "basic" plans.

The major changes between this set of plans and the "basic" optimum plans occurred in cropland use. While corn grain continued to be produced for swine feeding the small grains were harvested as hay as opposed to grain in the "basic" plans. For example, oat hay was included in all the large farm optimum plans, since spring labor had to be hired for the large farm plans. When oats for grain were required for feeding sheep, they were produced on Class II upland cropland.

A major change also occurred in the utilization of Class III upland. Whereas the "basic" plans included intensive rotations for Class III upland, little or none was used for orchardgrass hay production. However, when grain selling alternatives were permitted, rotations on this cropland included orchardgrass hay pro- duction for three years. In addition, the farm plans of Study Area III included rotations with orchardgrass for ten years on Class IV upland. As a consequence of shifting cropland to the more extensive (longer) rotations on all the study farms, increased tonnages of hay were sold as compared to the "basic" option.

Pasture continued to be completely utilized in an unimproved state. While small acreages of unimproved pasture were used in the farm organizations which had sheep, the major portion of the pastureland was rented out. The available ACP funds continued to be used for hayland improvement or to go unused, indicating again that pastureland improvement was not profitable.

Class I cropland, capital, building space, and spring labor continued to be restrictive resources as in the "basic" optimum plans, but showed little change in VMP. However, the VMP's for Classes II, III, and IV cropland decreased by $\$ 4$ to $\$ 7$ from the same cropland classes in the "basic" plans (Table 4). These decreases in VMP's were due to the small grains being harvested as hay instead of grain in these plans.

Optimum Farm Plans Obtained with all Alternatives, Except Dairy, Considered and with Market Hog Production Restricted to 125 Head per Market Period

The resultant farm plans from imposing a size limit of 125 head per market period on market hog production are presented in Table 7 . Restricting market hog production to this level caused the net income values of these plans to decrease substantially from the "basic" optimum plans, especially those of the large size farms. The decreases in net income values for this option were $\$ 8,700, \$ 7,300$ and $\$ 6,400$ for the large size farms, and $\$ 2,900, \$ 2,200$ and $\$ 500$ for the small size farms, in Study Areas I, II and III, respectively.

All of these optimum plans included the maximum number of hogs permitted; 125 head per market period (Table 7$)$. Further, with hog production limited, resources were used to expand sheep numbers substantially above the level included in the "basic" optimum plans. In Study Areas I, II, and III, respectively, the large farms had 482; 340; and 290 ewes, and the small farms had 185; 150; and 162 ewes in these optimum plans (Table 7 ). Of particular note both the large and the small farm plans in Study Area II included a sizeable sheep enterprise whereas neither included any sheep in the "basic" optimum plans.

TABLE 6. Optimum farm plans obtained with all alternatives considered, except dairy and selling of grains, for two farm sizes in each of three study areas.

\begin{tabular}{llcccccc}
\hline \hline & & Study & Area I & & Study & Area II & \multicolumn{2}{c}{ Study Area III } \\
Item & Unit & Large & Small & Large & Small & Large & Small \\
Larm & Farm & Farm & Farm & Farm & Farm \\
\hline Net Income: & Dollars & $39,500.0$ & $18,200.0$ & $29,600.0$ & $13,900.0$ & $25,200.0$ & $11,400.0$
\end{tabular}

Livestock:

February market hogs

July market hogs

Sheep

$\begin{array}{lrrrrrr}\text { Head } & 1,126.0 & 568.0 & 975.0 & 500.0 & 803.0 & 370.0 \\ \text { Head } & 1,126.0 & 568.0 & 975.0 & 500.0 & 803.0 & 370.0 \\ \text { Ewes } & 85.0 & 8.0 & 0.0 & 0.0 & 20.0 & 63.0\end{array}$


Table 6 (continued)

Land Utilization:

Class I, bottomland

Continuous corn grain

Acre

$112.0 \quad 50.0$

41.0

29.0

0.0

0.0

Class II, bottomland

Corn grain, 2 years

Wheat hay

Clover hay, alone, 2 years

Acres

4.0

0.0

0.0

0.0

Acres

2.0

0.0

0.0

Acres

0.0

0.0

0.0

0.0

Class III, bottomland

Corn grain, 1 year

Acres

Oats hay

Wheat hay

Clover hay, alone, 2 years

Clover hay, rotation, 2 years

Orchardgrass hay, 3 years

Acres

Acres

Acres

Acres

Acres

Class II, upland

Corn grain, 2 years

Oats grain

Wheat hay

Oats hay

Clover hay, alone, 2 years

Clover hay, rotation, 2 years

Orchardgrass hay, 3 years

Acres

0.0

0.0

3.0

2.4

0.0

0.0

0.0

2.4

3.0

0.0

0.0

0.0

0.0

6.0

0.0

0.0

0.0

0.0

0.0

0.0

4.9

7.3

0.0

0.0

0.0

0.0

0.0

0.0

6.4

27.2

$\begin{array}{lrr}4.8 & 6.4 & 40.8 \\ 1.1 & 0.1 & 0.0\end{array}$

Acres

Acres

Acres

Acres

Acres

Acres

Class III, upland

Corn grain, 1 year

Wheat hay

Oats hay

Acres

Acres

Acres

Clover hay, alone, 2 years

Acres

Clover hay, rotation, 2 years

Acres

Orchardgrass hay, 3 years

Acres

Class IV, upland

Wheat hay

Oats hay

Clover hay, rotation, 2 years

Acres

Acres

Acres

Acres

Orchardgrass hay, 3 years

Acres

1.1

0.1

$0.0 \quad 20.4$

1.3
0.0

3.1

0.0

40.8

0.0

4.8
0.0

0.0

0.0

0.0

0.0

0.0

0.2

13.4

0.0

27.2

0.0

6.4

0.0

0.0

5.8

1.2

0.5

5.8

0.0

5.7

0.0

8.8

0.0

0.5

0.0

0.0

2.4

1.0

0.0

3.2

0.0

$1.6 \quad 11.4$

$0.0 \quad 11.4$

$1.6 \quad 0.0$

$\begin{array}{ll}2.6 & 20.6\end{array}$

0.5

0.7

2.2

3.4

$1.7 \quad 0.0$

4.0

0.0

0.0

1.2

0.0

8.0

12.0

5.0

0.0

0.0

Purchases:

Fall feeder pigs

Spring feeder pigs

Corn grain

Straw

Clover hay

Clover-grass hay

Spring labor

Sales:

February market hogs

July market hogs

Lambs

Clover hay

Clover-grass hay

Orchardgrass hay

Pasture

Other:

Operating capital

Investment capital Total capital

Transfer pasture
ACP funds used for hayland

Cwt.

Cwt.

Bushel

Tons

Tons

Tons

Hours

563.0

284.0

487.5

487.5

284.0

487.5

563.0

$3,530.0$

28.3

48.8

0.0

0.0

0.0

24.0

Cwt.

Cwt.

Cwt.

Tons

Tons

Tons

A.U.

Dollars

Dollars

Dollars

A.U. 7.5

184.0

0.0

$2,477.0 \quad 1,249.6$

$2,145.0$

$$
2,477.0
$$

$1,249.6$

10.4

116.0

0.0

0.0

52.4

0.0

3.0

26.4

94.0

$2,145.0$

0.0

87.2

10.6

94.7

206.0

\section{0}

2.0

3.0

0.0

3.6

0.0

7.2

0.0

36.2

0.0

0.0

0.0

0.0

10.5

0.8

0.0

4.5

8.0

2.5

3.7

1.7

0.0

1.7

0.0

3.4

5.2

250.0

250.0

$5,558.0$

25.0

0.0

0.0

401.5

401.5

$11,552.0$

39.7

39.7
0.0

0.0

167.0

0.0

0.8

1.7

0.0

8.5

185.0

185.0

$5,990.0$ 
TABLE 7. Optimum farm plans with all alternatives considered, except dairy, with $\mathrm{m}$ a $\mathrm{r} \mathrm{k}$ e $\mathrm{t}$ hogs imited to a maximum production of 125 head per period for two farm sizes in each of three study areas.

\begin{tabular}{|c|c|c|c|c|c|c|c|}
\hline $\mathrm{m}$ & Unit & $\begin{array}{l}\text { Study } \\
\text { Large } \\
\text { Farm }\end{array}$ & $\begin{array}{c}\text { Area I } \\
\text { Small } \\
\text { Farm }\end{array}$ & $\begin{array}{l}\text { Study } \\
\text { Large } \\
\text { Farm }\end{array}$ & $\begin{array}{c}\text { Area II } \\
\text { Small } \\
\text { Farm }\end{array}$ & $\begin{array}{l}\text { Study } \\
\text { Large } \\
\text { Farm }\end{array}$ & $\begin{array}{c}\text { Area III } \\
\text { Small } \\
\text { Farm }\end{array}$ \\
\hline & Dolla & $31,100.0$ & $15,400.0$ & $23,000.0$ & $11,900.0$ & $19,800.0$ & $11,200.0$ \\
\hline
\end{tabular}

Net Income:

Dollars $31,100.0 \quad 15$,

Livestock:

February market hogs

July market hogs

Sheep

Land Utilization:

\section{Class I, bottomland}

Continuous corn grain

Class II, bottomland

Corn grain, 2 years

Wheat grain

Clover hay, alone, 2 years

Class III, bottomland

Corn grain, 1 year

Oats grain

Clover hay, alone, 2 years

Clover hay, rotation, 2 years

Orchardgrass hay, 3 years

Class II, uplanà

Corn grain, 2 years

Wheat grain

Oats grain

Clover hay, alone, 2 years

Clover hay, rotation, 2 years

Orchardgrass hay, 3 years

Class III, upland

Corn grain, 1 year

Wheat grain

Oats grain

Clover hay, alone, 2 years

Clover hay, rotation, 2 years

Orchardgrass hay, 3 years

Class IV, upland

Wheat grain

Clover hay, rotation, 2 years

Orchardgrass hay, 3 years

Acres

112.0

50.0

4.0

Acres

Acres

Acres

2.0

4.0

0.0

0.0

0.0

Acres

Acres

Acres

Acres

Acres

Acres

Acres

Acres

Acres

Acres

Acres

Acres

Acres

Acres

Acres

Acres

Acres

Acres

Acres

Acres

Pasture, bottomland, unimproved Acres

Pasture, upland, unimproved

Acres

Purchases:

Fall feeder pigs

Spring feeder pigs

Corn grain

Oats grain

Clover-grass hay

Spring labor

Fall labor
Cwt.

Cwt.

Bushels

Bushels

Tons

Hours

Hours

\section{0}

0.0

0.0

0.0

0.0

0.0

0.0

0.0

0.0

0.0

4.8

0.0

2.4

4.8

0.0

0.0

5.8

5.8

0.0

5.7

5.9

8.8

\section{0}

2.0

0.0

0.0

4.0

6.0

1.2

1.1

0.0

0.0

2.3

3.4

1.7

3.3

5.0

1.2

2.4

3.4

74.0

49.0

530.0

269.0

62.5

62.5

0.0

207.0

86.3

356.0

35.0

62.5

62.5

0.0

126.0

23.9

0.0

0.0

\section{0 \\ 125.0}

340.0

125.0
125.0

150.0

125.0

125.0

290.0

125.0

125.0

162.0

\section{(continued on next page)}

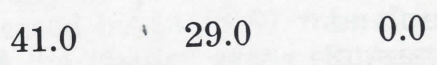

0.0

0.0

0.0

0.0

0.0

0.0

0.0

0.0

0.0

0.0

0.0

0.0

0.0

3.0

2.4

2.4

0.0

6.0

0.0

4.9

7.3

0.0

0.0

0.0

0.0

0.0

0.0

0.0

0.0

0.0

0.0

40.8

19.9

0.5

40.8

0.0

0.0

6.4

27.2

10.1

0.0

0.0

13.6

27.2

0.0

6.4
0.0

0.0

0.0

0.5

0.0

0.5

1.0

0.0

0.0

1.4

0.0

7.0

7.0

0.0

0.0

1.7

1.0

14.0

21.0

\section{0}

8.0

12.0

1.0

2.0

7.8

15.7

23.7

46.0

511.0

35.0

305.0

0.0

443.0

0.0

250.0

62.5
62.5
0.0
0.0
0.0
183.0
0.0

62.5

62.5

62.5

62.5

0.0

62.5

0.0

197.0

0.0
0.0

8.2

288.0

0.0

0.0
62.5

$1,193.9$

110.0

0.0

0.0

0.0 
Table 7 (continued)

Sales:

February market hogs

July market hogs

Lambs

Corn grain

Wheat grain

Oats grain

Straw

Clover hay

Orchardgrass hay

Pasture

Other:

Operating capital

Investment capital

Total capital

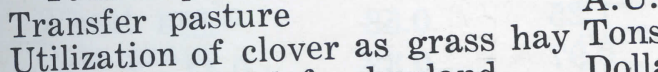

ACP funds used for hayland

$\begin{array}{lr}\text { Cwt. } & 275.0 \\ \text { Cwt. } & 275.0 \\ \text { Cwt. } & 660.0 \\ \text { Bushels } & 14,537.0 \\ \text { Bushels } & 241.0 \\ \text { Bushels } & 0.0 \\ \text { Tons } & 21.3 \\ \text { Tons } & 0.0 \\ \text { Tons } & 29.1 \\ \text { A.U. } & 70.4\end{array}$

Dollars

Dollars

Dollars

A.U.

Dollars

$\begin{array}{rr}18,600.0 & 10,700.0 \\ 10,900.0 & 4,100.0 \\ 29,500.0 & 14,800.0 \\ 113.0 & 59.9 \\ 0.0 & 3.6 \\ 400.0 & 400.0\end{array}$

275.0
275.0
465.6
$7,064.0$
678.0
0.0
50.5
66.3
34.2
130.0

$14,200.0$

$7,700.0$

$21,900.0$

102.8

0.0

400.0

$\begin{array}{rr}275.0 & 275.0 \\ 275.0 & 275.0 \\ 205.2 & 397.8 \\ 1,878.0 & 1,365.0 \\ 30.0 & 836.0 \\ 327.0 & 0.0 \\ 9.7 & 50.3 \\ 3.1 & 126.4 \\ 26.3 & 155.9 \\ 93.0 & 116.0\end{array}$

275.0

275.0

221.5

0.0

254.0

0.0

11.1

18.7

54.1

66.0

\begin{tabular}{rrr}
$9,000.0$ & $13,100.0$ & $8,500.0$ \\
$3,300.0$ & $6,400.0$ & $3,600.0$ \\
$12,300.0$ & $19,500.0$ & $12,100.0$ \\
63.1 & 76.8 & 43.4 \\
20.0 & 0.0 & 13.8 \\
400.0 & 400.0 & 400.0 \\
\hline
\end{tabular}

The total capital required for operating and investment purposes for these plans was $\$ 29,500$, $\$ 21,900$, and $\$ 19,500$ for the large farms and $\$ 14,800$, $\$ 12,300$, and $\$ 12,100$ for the small farms in Study Areas I, II, and III, respectively. These capital requireenly about one-third of those for each ments are only "basic" optimum plans, and hence, capacity was not restrictive. Further, capital borrowing constituted from onefourth to one-third of the total capital requirements for these optimum farms.

Since hog production was severely limited corn in substantially, except in the Study Area III small farm plan in which 1,200 bushels of corn Area III small farm plan in which grain were purchased. This was " were purchased

same size farm.

Tat utilized in each farm and cropland utilization was very similar to that plan "basic plans for each of the farms. However, of the "basic" plans for III upland cropland was a greater acreage of Class utilized for three years of orchardgrass orchardgrass none of the cropland rotations included ar income hay for 10 years. Hay selling continued as an income source, specifically clover hay sales, which increased hay contrasted to orchardgrass hay. Increased clover hay sales can be attributed to reduced requirements by the smaller number of hogs, and to the difference in the price of clover hay compared to orchardgrass hay.

Pastureland continued to be utilized in an unimproved state. And, less pastureland was rented-out under this option than in the "basic" optionded sheep enincreased need for pasture by the expandized for hay terprises. All available ACP funds with none allotted to establishment and maintenar

pastureland improvement.

Under this option, cropland and livestock building space were the only restrictive resources for all farms, while labor remained restrictive for all the large farm by $\$ 15$ to $\$ 35$ per acre from those of the "basic" optimum plans (Tables 4 and 8 ). The decreases in VMP's on the other classes of cropland were, in general, smaller. These decreased VMP's for cropland indicate that the market hog alternative would utilize the farms' resources more profitably than the sheep alternative as corn was more profitably converted to pork than sold as grain.

\section{Optimum Farm Plans Obtained with all Alternatives Considered, Including Dairy}

The conventional linear programming model used $r$ these analyses assumes enterprise production processes to be infinitely divisible. Consequently, to assure cesse dairy enterprise in the analysis, at least a minimum labor rethe establishment costs and forced into quired for a minimum 50-cow he divisibility assumpthe planning model to override the this was done, a tion of linear programming. Once this walues and comparison was made of the net income valu a dairy resource utilization between plans permitting all liveoption and the "basic" plans which permitted stock alternatives except dairy.

The optimum farm plans determined when all alternatives including dairy were considered are found in Table 9. These optimum plans yielded net income values exceeding those of all other options analyzed in this study. The large farm plans yielded net incomes of $\$ 57,400, \$ 42,800$, and $\$ 38,300$ for Study Areas I, II, and III, respectively, while the small farm plans yielded net incomes of $\$ 28,000, \$ 20,500$, and $\$ 20,100$. Coma "basic" plans (Table 3), these net income pared to the "rom 41 to 46 per cent greater for the values ranged from 41 to large farms and from 45 to 72 pelative greater profitability small farms, indicating the relative greater.

of dairy for use of the available resourcestock enter-

A dairy enterprise was the only livestock sizes of prise included in these optimum plans. He large farm $112 ; 92 ;$ and 80 cows were included in the large farm
plans, and $53 ; 47 ;$ and 50 cow herd sizes in the small 
TABLE 8. Value of the marginal products (VMP's) for restrictive resources for optimum plans obtained with market hogs limited to a maximum production of 125 head per market period for two farm sizes in each of the three study areas.

\begin{tabular}{|c|c|c|c|c|c|c|c|}
\hline Item & Unit & $\begin{array}{l}\text { Study } \\
\text { Large } \\
\text { Farm }\end{array}$ & $\begin{array}{c}\text { Area I } \\
\text { Small } \\
\text { Farm } \\
\end{array}$ & $\begin{array}{l}\text { Study } \\
\text { Large } \\
\text { Farm }\end{array}$ & $\begin{array}{c}\text { Area II } \\
\text { Small } \\
\text { Farm } \\
\end{array}$ & $\begin{array}{l}\text { Study A } \\
\text { Large } \\
\text { Farm }\end{array}$ & $\begin{array}{c}\text { Area III } \\
\text { Small } \\
\text { Farm } \\
\end{array}$ \\
\hline \multicolumn{8}{|l|}{$\begin{array}{l}\text { Item } \\
\text { Cropland: }\end{array}$} \\
\hline $\begin{array}{l}\text { Class I, bottomland } \\
\text { Class II, bottomland }\end{array}$ & $\begin{array}{l}\text { Acres } \\
\text { Acres }\end{array}$ & $\begin{array}{r}\$ 132.95 \\
70.62\end{array}$ & $\$ 145.06$ & $\$ 105.25$ & $\$ 111.53$ & - & - \\
\hline & $\begin{array}{l}\text { Acres } \\
\text { Acres }\end{array}$ & -10.02 & - & 45.83 & 55.86 & - & 一 \\
\hline $\begin{array}{l}\text { Class III, bottomland } \\
\text { Class II, upland }\end{array}$ & $\begin{array}{l}\text { Acres } \\
\text { Acres }\end{array}$ & 64.35 & 72.27 & 75.67 & 81.07 & $\$ 78.27$ & $\$ 102 . \overline{70}$ \\
\hline $\begin{array}{l}\text { Class } 11 \text {, upland } \\
\text { Class III, upland }\end{array}$ & Acres & 49.65 & 61.21 & 61.40 & 66.77 & 71.11 & 92.34 \\
\hline Class IV, upland & Acres & 43.00 & 55.25 & 55.91 & 67.56 & 66.07 & 83.29 \\
\hline \multicolumn{8}{|l|}{$\begin{array}{l}\text { Class IV, upland } \\
\text { Pastureland: }\end{array}$} \\
\hline Bottomland & Acres & 0.63 & 0.58 & 1.25 & 0.58 & - & - \\
\hline Upland & Acres & 0.13 & 0.09 & 0.97 & 0.32 & 0.44 & 0.46 \\
\hline Livestock building space: & Sq. Ft. & 0.99 & 1.10 & 0.98 & 1.11 & 1.02 & 1.08 \\
\hline Silo capacity: & Tons & N.R. ${ }^{a}$ & N.R. & N.R. & N.R. & N.R. & N.R. \\
\hline \multicolumn{8}{|l|}{ Silo capacity: } \\
\hline Winter & Hours & N.R. & N.R. & N.R. & N.R. & N.R. & N.R. \\
\hline Spring & Hours & 1.14 & N.R. & 1.12 & N.R. & 1.18 & N.R. \\
\hline Summer & Hours & N.R. & N.R. & N.R. & N.R. & N.R. & N.R. \\
\hline Fall & Hours & 1.14 & N.R. & N.R. & N.R. & N.R. & N.R. \\
\hline \multicolumn{8}{|l|}{$\begin{array}{l}\text { Fall } \\
\text { Capital: }\end{array}$} \\
\hline $\begin{array}{l}\text { Operating } \\
\text { Investment }\end{array}$ & $\begin{array}{l}\text { Dollar } \\
\text { Dollar }\end{array}$ & $\begin{array}{l}\text { N.R. } \\
\text { N.R. }\end{array}$ & $\begin{array}{l}\text { N.R. } \\
\text { N.R. }\end{array}$ & $\begin{array}{l}\text { N.R. } \\
\text { N.R. }\end{array}$ & $\begin{array}{l}\text { N.R. } \\
\text { N.R. }\end{array}$ & $\begin{array}{l}\text { N.R. } \\
\text { N.R. }\end{array}$ & $\begin{array}{l}\text { N.K. } \\
\text { N.R. }\end{array}$ \\
\hline Investment & & & & & & & \\
\hline
\end{tabular}

" "where value for aN.R. represents
the farm plan.

TABLE 9. Optimum farm plans with all alternatives considered, including dairy, for two farm sizes in each of three study areas.

\begin{tabular}{|c|c|c|c|c|c|c|c|}
\hline Item & Unit & $\begin{array}{l}\text { Study } \\
\text { Large } \\
\text { Farm }\end{array}$ & $\begin{array}{c}\text { Area I } \\
\text { Small } \\
\text { Farm }\end{array}$ & $\begin{array}{l}\text { Study } \\
\text { Large } \\
\text { Farm }\end{array}$ & $\begin{array}{c}\text { Area II } \\
\text { Small } \\
\text { Farm }\end{array}$ & $\begin{array}{l}\text { Study } \\
\text { Large } \\
\text { Farm }\end{array}$ & $\begin{array}{c}\text { Area III } \\
\text { Small } \\
\text { Farm }\end{array}$ \\
\hline Net Income: & Dollars & $57,400.0$ & $28,300.0$ & $42,800.0$ & $20,500.0$ & $38,300.0$ & $20,100.0$ \\
\hline $\begin{array}{l}\text { Livestock: } \\
\text { Dairy cows }(13,000 \text { pounds } \\
\text { production) } \\
\text { Raised heifer replacements }\end{array}$ & $\begin{array}{l}\text { Head } \\
\text { Head }\end{array}$ & $\begin{array}{r}112.0 \\
14.0\end{array}$ & $\begin{array}{r}53.0 \\
2.0\end{array}$ & $\begin{array}{r}92.0 \\
0.0\end{array}$ & $\begin{array}{r}47.0 \\
0.0\end{array}$ & $\begin{array}{r}80.0 \\
0.0\end{array}$ & $\begin{array}{r}50.0 \\
0.0\end{array}$ \\
\hline $\begin{array}{l}\text { Land Utilization: } \\
\text { Class I, bottomland } \\
\text { Continuous corn grain } \\
\text { Continuous corn silage }\end{array}$ & $\begin{array}{l}\text { Acres } \\
\text { Acres }\end{array}$ & $\begin{array}{r}108.2 \\
3.8\end{array}$ & $\begin{array}{r}50.0 \\
0.0\end{array}$ & $\begin{array}{l}28.7 \\
12.3\end{array}$ & $\begin{array}{r}22.7 \\
6.3\end{array}$ & $\begin{array}{l}0.0 \\
0.0\end{array}$ & $\begin{array}{l}0.0 \\
0.0\end{array}$ \\
\hline $\begin{array}{l}\text { Class II, bottomland } \\
\text { Corn silage, } 2 \text { years } \\
\text { Oats grain } \\
\text { Clover, alone, } 2 \text { years }\end{array}$ & $\begin{array}{l}\text { Acres } \\
\text { Acres } \\
\text { Acres }\end{array}$ & $\begin{array}{l}4.0 \\
2.0 \\
4.0\end{array}$ & $\begin{array}{l}0.0 \\
0.0 \\
0.0\end{array}$ & $\begin{array}{l}0.0 \\
0.0 \\
0.0\end{array}$ & $\begin{array}{l}0.0 \\
0.0 \\
0.0\end{array}$ & $\begin{array}{l}0.0 \\
0.0 \\
0.0\end{array}$ & $\begin{array}{l}0.0 \\
0.0 \\
0.0\end{array}$ \\
\hline
\end{tabular}

(continued on next page) 
Table 9 (continued)

Class III, bottomland Corn grain, 1 year Oats grain Clover hay, alone, 2 years Clover hay, rotation, 2 years Orchardgrass hay, 3 years

Class II, upland Corn grain, 2 years

Corn silage, 2 years

Wheat grain

Oats grain

Clover hay, alone, 2 years

Class III, upland

Corn grain, 1 year

Corn silage, 1 year

Wheat grain

Oats grain

Clover hay, alone, 2 years

Class IV, upland

Wheat grain

Oats grain

Clover hay, alone, 2 years

Clover hay, rotation, 2 years

Orchardgrass hay, 3 years

Pasture, bottomland, unimproved Acres

Pasture, upland, unimproved

Pasture, upland, unused

Purchases:

Heifer replacements

Oats grain

Corn grain

Straw

Clover hay

Pasture

Winter labor

Spring labor

Summer labor

Fall labor

Sales:

Milk

Dairy calves

Corn grain

Wheat grain

Clover hay

Clover-grass hay

Orchardgrass hay

Pasture

Other:

Operating capital

Investment capital

$$
\text { Total capital }
$$

Dairy establishment

Dairy expansion (above 50 cows)

Transfer pasture

ACP funds used for hayland
Acres

Acres

Acres

Acres

Acres

Acres

Acres

Acres

Acres

Acres

Acres

Acres

Acres

Acres

Acres

Acres

Acres

Acres

Acres

Acres

Acres

Acres

Head

Bushels

Bushels

Tons

Tons

A.U.

Hours

Hours

Hours

Hours

Cwt.

Cwt.

Bushels

Bushels

Tons

Tons

Tons

A.U.

Dollars

Dollars

Dollars

Head

Head

A.U.

Dollars

$\begin{array}{ll}0.0 & 0.0 \\ 0.0 & 0.0 \\ 0.0 & 0.0 \\ 0.0 & 0.0 \\ 0.0 & 0.0\end{array}$

0.0

4.8

0.0

2.4

4.8

0.0

8.0

0.0

8.0

16.0

0.0

1.7

0.0

3.3

5.0

74.0

0.0

530.0

14.0

$6,222.0$

0.0

115.8

209.2

68.0

505.0

829.0

64.0

408.0

$$
14,560.0
$$

48.6

$12,135.0$

0.0

0.0

3.3

10.5

0.0

$36,900.0$

$64,200.0$

$101,100.0$

50.0

62.0

17.3

144.0

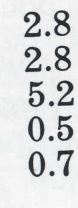

40.8

0.0

0.0

20.4

40.8

3.2

6.4

0.0

2.0

0.0

2.0

4.0

0.5

0.0

0.0

0.5

1.0

0.0

2.2

3.8

0.4

0.6

49.0

84.2

184.8

11.0

$2,963.0$

0.0

51.7

0.0

0.0

0.0

24.0

0.0

0.0

$6,890.0$
25.5
$5,570.0$
0.0
0.0
0.4
0.0
0.0

$17,400.0$ $35,300.0$

$52,700.0$

50.0

3.0

$$
\begin{array}{r}
3.0 \\
27.0 \\
0.0
\end{array}
$$

0.0

0.0

4.2

0.0

8.4

11.4

46.0

511.0
2.4
2.4

0.0

4.9

7.3

6.4

0.0

0.0

3.2

6.4

0.0

0.0

0.0

0.0

0.0

27.2

0.0

13.2

0.0

27.2

$1.7 \quad 1.0$

$0.0 \quad 11.3$

$0.0 \quad 12.3$

$\begin{array}{ll}0.7 & 0.0\end{array}$

$3.6 \quad 24.4$

0.0

0.0

\section{8}

1.0

0.0

2.0

3.0

35.0

305.0

0.0

12.0

23.0

$3,955.0$

0.0

58.4

64.8

0.0

26.0

661.0

165.0

143.0

\section{$11,960.0$}

46.0

$5,844.0$

0.0

0.0

10.4

32.2

128.5

$28,000.0$

$52,500.0$

$80,500.0$

$14,800.0$

$27,800.0$

$42,600.0$

600.0

42.0

103.0

20.0

0.0

0.0

0.0

0.0

0.0

0.0

\section{2}

3.8

6.0

0.0

12.0

0.0

3.0

0.0

3.0

6.0

0.0

3.0

4.8 
farm plans for Study Areas I, II, and III respectively (Table 9). Of the dairy ration alternatives considered, only the dairy ration having one pound of grain for each 4.75 pounds of milk and permitting 13,000 pounds milk production per cow entered these optimum farm plans. Except for the optimum plans for Study Area I all replacement animals were purchased, and even in the Study Area I optimum plans, the number of replacements purchased equalled or exceeded the number raised.

The total of operating and investment capital required for these farm plans was considerably greater than that required in the "basic" plans. Total capital requirements were $\$ 31,200, \$ 16,200$, and $\$ 8,400$ greater for the large farms and $\$ 17,700, \$ 9,400$, and $\$ 13,200$ greater for the small farms in Study Areas I, II, and III. Investment capital for acquiring livestock, adapting buildings for dairy, building and equipping a milk parlor and milk room, and other similar requirements for establishing a dairy enterprise constituted about 65 per cent of the total capital requirements for these optimum plans.

Livestock building space was a limiting factor for all optimum plans containing a dairy enterprise. This was especially true for the small farm optimum plans in Study Areas II and III in which unavailable building space restricted herd expansion above the initial 50cow capacity while capital borrowing capacity went unused.

Total cropland available was utilized in each optimum farm plan. And, in each of these optimum farm plans adequate acreages of corn silage were grown to meet the roughage needs of the dairy herd. Although the dairy alternative was the only option for which any of the available silo capacity was utilized, it was not a restrictive resource even for this option. Intensive rotations (maximum of two years of clover hay) appeared in all the optimum plans; Class III bottomland and Class IV upland cropland were utilized in rotations consisting of three years of orchardgrass hay. Some hay was sold, with the total tonnage sold nearly the same as the total hay tonnage sold in the "basic" plans, area by area and farm by farm. A departure from the "basic" plans was the sizeable quantities of corn grain sold in each of the farm plans except for the Study Area III small farm plan which required the purchase of 366 bushels of corn to maintain the dairy herd. While oais were the primary small grain in the rotations, the quantities produced were insufficient to meet the needs of the dairy herd. Therefore, oat grain was purchased in large quantities in each of the optimum dairy farm plans.

Additional labor was hired for all seasons, especially in spring, in the large farm plans in Study Areas I and II and for all periods, except winter in the large farm plan in Study Area III. The Study Area I small farm plan was the only small farm plan to include hiring any seasonal labor, and here the quantity of spring labor hired ( 24 hours) was too small to have any practical meaning.

In Study Areas II and III, all pastureland was utilized in an unimproved state, and pasture not needed by the dairy enterprise was rented-out. In the optimum plan for the large farm in Study Area I, capital was restricting, additional summer labor was hired, and the total upland pastureland was unused. The Study Area I small farm utilized, in an unimproved state, all bottomland pasture acreage and 85 acres of the upland pasture. However, approximately 185 acres of upland pasture acreage went unused in this farm plan when all unpaid family labor available for the summer season was completely utilized. This resulted from fence repair being assumed to require summer labor in the analyses, and it being unprofitable to hire summer labor for this chore. As in the preceeding optimum plans, available ACP funds were used for hay establishment and maintenance or left unused rather than utilized for pastureland improvement.

Both cropland and building space were limiting resources for all the dairy optimum plans. Capital and/ or labor were limiting in some plans.

The VMP's for cropland, generally, were slightly less in the dairy optimum farm plans as compared to the "basic" plans (Table 10 ), again reinforcing the profitability of crop production as a revenue source compared to other alternatives. It can be concluded that this was due to corn silage being produced instead of corn grain. However, the optimum plan for the small farm in Study Area III had substantially higher VMP's for cropland than in the "basic" plan, and the small farm plan in Study Area II had slightly higher VMP's for Class III bottomland, and for Class III and IV upland cropland.

Livestock building space was a very restrictive resource for those farm plans with unused capital capacity. The large and small farm plans in Study Area II and the large farm plan of Study Area III had VMP's for building space per square foot of $\$ 3.25, \$ 3.93$, and $\$ 3.57$, respectively, which was substantially greater than this resource VMP's in the "basic" plans. These higher VMP's for the optimum plans which included dairy are indicative of the relative greater profitability of dairy compared to the other livestock alternatives considered in the "basic" plans. Further, for those farm plans having sufficient building space the dairy herd did expand above the initial 50-cow capacity, which is further indicative of the greater profitability of dairy as compared to market hogs in utilizing the resources available on these farms.

Capital was restrictive for both size farms in Study Area I and the small farm of Study Area III. The optimum plans for these farm resource situations indicated that interest rates of 41.0 per cent and 48.0 per cent for the large and small farms of Study Area I and of 39.0 per cent for the Study Area III small farm could be paid for additional operating capital, respectively. Rates of only one per cent less than for operating capital were indicated as profitable for acquiring additional investment capital.

The large farm plans in all the study areas included hiring additional labor. The VMP's indicated in these optimum plans were (1) \$1.55 per hour for labor in all seasons for the Study Area I large farm, and (2) $\$ 1.19$ per hour for all seasons on large farms in the other study areas. The analysis also indicated that for the small farm plan in Study Area I, additional spring 
TABLE 10. Value of the marginal products (VMP's) for restrictive resources for optimum plans con-

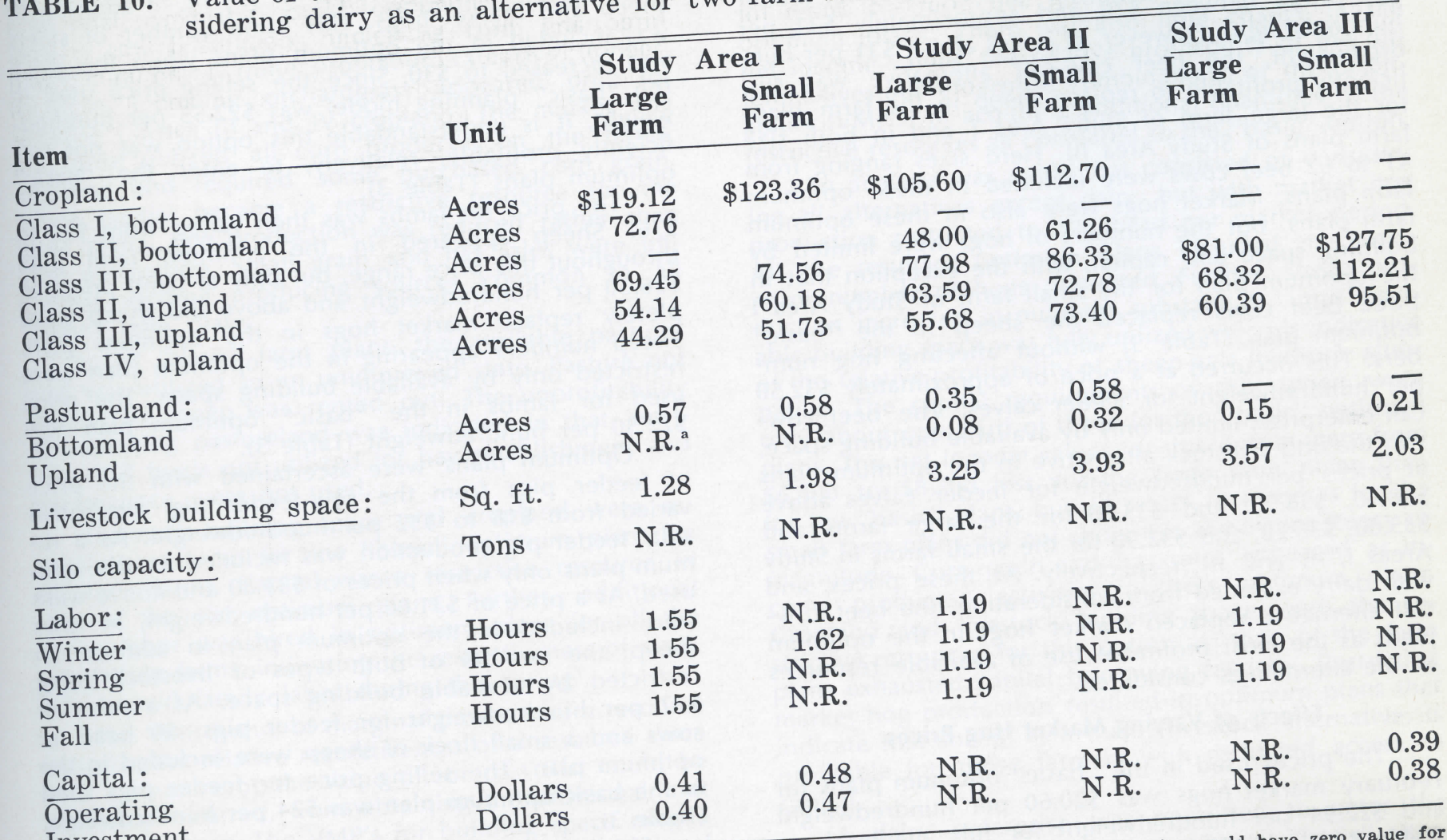

Investment

aN.R. represents the farm plan.

labor could be profitably hired for $\$ 1.62$ per hour if additional capital were available.

EFFECTS OF PRICE VARIABILITY ON OPTIMUM PLANS

To assess the effects of variation in prices of livestock products on the stability of optimum plans obained, price mapping procedures were employed for the alternative livestock products. ${ }^{23}$ Price mapping is a procedure by which the prices for products (and/or inputs) are permitted to change over a given range. ${ }^{24}$ procedure, prices the given product being mapped are changed relative to prices of other When the relationship product alternatives consider the enterbetween prices changes enough to differ from the prise combination in a farm plan the product and the resulting change in the option. For the parare indicated in the programmed solution study, price ticular computer program available one product at a mapping could only be done for on remaining contime, with prices for all other products remaining constant.

Price mapping was employed mainly to determine the effects of price variability for market hogs and Prices for livestock products variations for these products considered.

${ }^{24} \mathrm{Heady}$, loc. eit.

feeder calves on optimum plans. The market hog and rices were seled for analysis since (1) eeder calf prices the most profitable livestock alternahogs were the mere included in the tive in the "basic" option able 3), and (2) the study "basic" optimum plans (Table farms were engaged in commarying these prices, the duction. Consequently, by varying were deterstability of the "basic" optimum which the beef cowmined as were the price levels at which thatable than calf enterprise would becomeluded in the optimum other livestock alternatives included in was excluded plans. In each instance, a dairy enten the market hog and as an alternative "a priori" whed.

feeder calves were price mapped.

Price mapping was done for only one farm sizes sidered in this study, as it was assumed effects of provide sufficient insight into the

other product price variability.

EFFECTS of VARYING FEEDER

The prices used in the "basic" analysis for feer steers were $\$ 27.21$ per hundredweight and

hundredweight for feeder heeder calf prices on the

The effects of changing for all six study farms "basic" optimum farm plans range of $\$ 20$ to $\$ 40$ per were determined for a price range of hundredweight. Both livestock alternatives and size of 
each enterprise in the resultant optimum plans were quite similar to the "basic" plans (Table 3) for feeder calf prices between $\$ 20$ and approximately $\$ 31$ per hundredweight. However, at prices above $\$ 31$ per hundredweight, the beef cow-calf alternative was sufficiently profitable to replace sheep in the farm plans for the large farm of Study Area I and in both size farm plans of Study Area III. Herd sizes ranging from 41 to 62 beef cows were included in these optimum farm plans. Market hogs were also in these optimum farm plans, but the numbers of hogs were limited by building space and capital, with the exception that in the optimum plan for the small farm of Study Area I three beef cows replaced the sheep in the "basic" optimum plan (Table 3) without affecting hog numbers. This occurred at a price of approximately $\$ 32.50$ per hundredweight for feeder calves. The beef cowcalf enterprise, limited only by available building space, was the only livestock alternative in the optimum plans at prices per hundredweight for feeder calves above $\$ 38.40$, $\$ 38.90$, and $\$ 35.20$ for the large farms and $\$ 35.80, \$ 36.20$, and $\$ 32.90$ for the small farms in Study Areas I, II, and III, respectively. At these prices, and with dairy excluded from consideration, the beef cowcalf alternative replaced market hogs in the optimum plans as the most profitable use of available resources of the alternatives considered.

\section{Effects of Varying Market Hog Prices}

The prices used in the "basic" optimum plans for February market hogs was $\$ 20.60$ per hundredweight and \$22.94 per hundredweight for July market hogs (Table 3).

The effects of varying hog prices within the range of $\$ 15$ and $\$ 30$ per hundredweight were determined for the "basic" optimum farm plans for all six study farms. With dairy not considered, market hogs were included in the resultant optimum plans at levels similar to those in the "basic" optimum plans (Table 3) at a price of $\$ 19.60$ per hundredweight. The optimum plans remained unchanged as price was increased to the $\$ 30$ price. At prices below $\$ 19.60$ hogs no longer were included, and sheep remained as the only livestock alternative in the optimum plans.

\section{Price Mapping Analyses of Other Livestock Alternatives}

Price mapping was done for those alternatives using only the Study Area I small farm to determine an indication of the effects of price variability for the other livestock alternatives considered in this study.

First, the price for the beef alternative of wintering feeder steers was price mapped from $\$ 20$ to $\$ 36$ per hundredweight. This alternative did not appear in any of the subsequent optimum plans, even at a price of $\$ 36$, which indicates the relative unprofitability of this enterprise compared to hogs and sheep, and explains partly why the alternative did not appear in the "basic" optimum plans (Table 3), since the price used in the basic plans was $\$ 27.90$ per hundredweight.

The price for the beef alternative for summer grazing of yearling steers was then varied from $\$ 15$ to $\$ 30$ per hundredweight. Sixty-three steers appeared in the optimum plans at a price of $\$ 25.14$, in addition to sheep and market hogs. This same number of steers was included in the optimum plans when the price was increased to $\$ 30$. Since the selling price used in the "basic" planning model was $\$ 22.55$ per hundredweight, it is understandable this option was not sufficiently profitable, relatively, to enter the "basic" optimum plans (Table 3)

The price for lambs was then varied from $\$ 20$ to $\$ 36$. Sheep appeared in the optimum farm plan throughout this price range, but only at lamb prices of $\$ 26.30$ per hundredweight and above did sheep completely replace market hogs in the optimum plan. Sheep numbers appearing in the optimum plan were restricted only by available building space. The price used for lambs in the "basic" optimum plan was $\$ 22.30$ per hundredweight (Table 3 ).

Optimum plans were ascertained with the price of feeder pigs from the sow-feeder pig alternative varied from $\$ 18$ to $\$ 32$ per hundredweight. As a result, feeder pig production was included in the optimum plans only when prices of $\$ 31.80$ and above were used. At a price of $\$ 31.80$ per hundredweight, 34 sows were included in the optimum plan in addition to sheep; the number of both types of livestock being restricted by available building space. At a price of $\$ 32$ per hundredweight for feeder pigs, 50 head of sows and a small flock of sheep were included in the optimum plan. The selling price for feeder pigs used in the basic optimum plan was $\$ 24$ per hundredweight (Table 3).

Finally, the dairy alternative was permitted to enter the farm plan. Milk price was varied from $\$ 3$ to $\$ 7$ per hundredweight. At the $\$ 3$ price, market hogs and sheep were included in the optimum plan as these livestock alternatives were in the basic plan for this farm (Table 3). But, at a milk price of $\$ 3.79$ per hundredweight, 44 dairy cows (producing 13,000 pounds of milk annually per cow) and 11 raised replacement heifers replaced the hogs and sheep in the optimum plan, and no* other livestock alternatives appeared in the optimum plan at or above the $\$ 3.79$ milk price. Further, the number of dairy cows increased to 53 head, but the number of raised heifers decreased to two head at a milk price of $\$ 4.49$ and above. The milk price used in the "basic" plan was $\$ 5.68$ per hundredweight.

\section{RESUME OF FARM PLANS}

The "basic" option considered for the farm resource situations analyzed in this study consisted of all feasible livestock enterprises except dairy. When all alternatives except dairy were considered, market hog production was the major livestock alternative in the "basic" optimum plans for all study farms. Small numbers of sheep were also included when capital became restrictive for additional market hog production. The size of both livestock alternatives in the "basic" optimum plans was ultimately restricted by available building space. No other livestock alternatives appeared in the "basic" optimum plans.

All cropland available was fully utilized in all farm plans. Cropland use was mainly influenced by 
the limitations placed on corn grain production. The crop rotations in the "basic" optimum plans were intensive (short duration), indicating corn grain production as being quite profitable. Extensive (longer) rotations including orchardgrass appeared only for utilizing Classes III and IV cropland. The market hog enterprise utilized all corn produced on the farms cropland and required some purchased corn grain. When captial became a restrictive resource for the basic plans, hog production was reduced rather than crop production. Small grain and hay sales were important income producing sources common to all "basic" farm plans.

In all "basic" farm plans, the available pastureland was utilized in an unimproved state. Pasture not utilized by sheep was rented out. The unprofitability of improving pastureland was indicated in that available ACP funds not utilized for hay establishment and maintenance were not used.

Livestock building space and cropland were restrictive resources for the "basic" optimum plans on all study farms. Capital was a restrictive resource in four of the six optimum plans. Further, additional spring labor was hired in optimum plans for all the large study farms, indicating the restrictiveness of available unpaid family labor during the spring.

The VMP (value of marginal product) of a resource indicates the relative restrictiveness of a resource since it is a measure of the value of, or cost that could be profitably incurred, from obtaining an additional unit of the resource. The VMP's for building space ranged from $\$ 0.90$ to $\$ 1.76$ per square foot, and, additional capital could have been profitably utilized, if available at rates of 16 per cent for operating capital and 15 per cent for investment capital. Additional spring labor could have been profitably hired, if capital were available, at rates ranging from $\$ 1.19$ to $\$ 1.28$ per hour.

When the alternatives of selling hay and pasture and the dairy alternative were excluded from consideration little change occurred in the optimum plans. However, in four of the six farm plans net income values decreased between $\$ 2,100$ and $\$ 7,800$. Further, in the optimum plans for these four study farms, all the Class IV cropland was unused, as well as some clover hay that was produced on other cropland and not used by the market hogs and/or sheep. This indicates the profitability of corn production in that this enterprise incurred all the costs of producing hay, which was unused, and still was profitable. For those classes of cropland on which corn grain production was allowed only in rotation, the VMP's decreased by $\$ 30-\$ 50$ per acre when hay sales were not permitted as an alternative.

The elimination of the alternatives for hay and pasture selling left the relative profitability of the livestock enterprise combinations unchanged. Further, the decrease in net incomes for four of the six farm plans indicates the importance of hay sales as an income producing source for the farm resources analyzed.

When all alternatives, other than dairy and grain selling, were considered, the optimum farm plans were quite similar to the "basic" plans. However, the small grains were harvested as hay in these plans as op- posed to grains in the "basic" optimum plans. Cropland, capital, building space, and spring labor continued to be restrictive resources as in the "basic" optimum plans. There was also little change in the net income values, the relative profitability of the different livestock enterprise combinations, or the profitability (VMP's) of acquiring additional quantities of the restrictive resources as compared to the "basic" option.

An analysis was made that consisted of considering all alternatives except dairy, but with market hog production restricted to 125 head per market period. All the resultant optimum plans included the maximum number of hogs permitted. Further, sheep production increased in numbers substantially until availduction increased in fully utilized which is indicative of the relative profitability of sheep as a livestock alternative. The capital requirements of this option were only about one-third of those for the "basic" optimum plans. The net income values for this option were from $\$ 6,400$ to $\$ 8,700$ less for the large farm plans than for the "basic" plans, but decreases in incomes for the small farm plans did not show this same consistency or magnitude. Corn grain and hay sales appeared as income producing activities in these optimum plans. Cropland and livestock building space were the restrictive resources for this option as none of the farm plans exhausted capital borrowing capacity. Restricting market hog production resulted in optimum plans that indicate that sheep, as a major livestock alternative, is profitable for those farmers with restricted access to capital.

A dairy enterprise was permitted to enter the planning model in competition with all "basic" alternatives considered. When permitted as an alternative, dairy was the only livestock enterprise appearing in the optimum plans for all six study farms. The dairy ration for the most intensive grain feeding option (allowing 13,000 pounds of milk production per cow per year) was the only one of the dairy rations considered to enter the optimum plans. These optimum plans containing a dairy enterprise had net income values $\$ 6,400-\$ 10,000$ higher for the small farms and $\$ 12,000$ $\$ 17,600$ higher for the large farms than were obtained in the "basic" optimum plans. Total capital requirements were, however, higher for plans with dairy than for other optimum plans. Capital requirements were $\$ 8,400-\$ 31,200$ greater for the large farm plans and $\$ 9,400-\$ 17,700$ greater for small farm plans as compared to the "basic" plans, with approximately 65 per cent of the total capital required being necessary for initial establishment of the dairy enterprise.

Livestock building space was a restrictive resource all dairy optimum plans. For two of the six study farm plans, limited building space restricted expansion above the initial 50 cow herd. The VMP's for building space ranged from $\$ 1.28$ to $\$ 3.93$ per square feet for the dairy optimum plans. All cropland was utilized in each of the optimum farm plans, and utilization was similar to the "basic" optimum plans. However, corn silage was produced on some land instead of corn grain to meet the forage needs of the dairy herd. Hence, this was the only option for which any available silo capacity was utilized, but silo capacity was 
not a restrictive resource even for this option. Further considerable quantities of corn grain were produced and sold in five of the six farm plans. Though included in the rotations, additional oats were purchased in large quantities for each of the dairy optimum plans.

Additional labor was hired in all seasons in two large farm plans; in all seasons, except winter, for another large farm plan; and in the summer period for a small farm plan. The labor VMP's ranged from $\$ 1.19$ to $\$ 1.62$ per hour for these dairy optimum plans.

Capital was restrictive in three of the six dairy optimum plans. The VMP's for capital for these plans indicated that interest rates ranging from 39.0 to 48.0 per cent could profitably be paid for additional operating capital and from 38.0 to 47.0 per cent for additional investment capital.

Four of the six dairy optimum plans utilized all pastureland in an unimproved state, while that not needed by the dairy herd would be rented-out, if possible. The other two dairy optimum plans left either all or most of the upland unused. Again, pastureland improvement was a relatively unprofitable alternative as ACP funds were either used for hay establishment and maintenance or unused.

To assess the effects of livestock products price variability on the stability of the "basic" optimum plans obtained, price mapping procedures were employed. With dairy excluded from consideration, and all other prices held constant, prices exceeding \$31 per hundredweight for feeder calves were required for the beef cow-calf alternative to replace the sheep alternative in all the "basic" optimum plans. Further, feeder calf prices ranging above $\$ 32.90$ to $\$ 38.90$ per hundredweight were required for the beef cow-calf alternative to completely replace market hog production in the different farm plans.

When price was varied between $\$ 15$ and $\$ 30$, market hogs were not included in the optimum plan at prices below $\$ 19.60$ per hundredweight, and sheep remained as the only livestock alternative in the optimum plans at the lower price levels.

Price mapping was done on one study area small farm for the other livestock alternatives. It was found that: (1) the beef alternative for wintering feeder steers did not appear in optimum plans even when price was as high as $\$ 36$ per hundredweight; (2) sheep completely replaced market hogs in the optimum plans at prices above $\$ 26.30$ per hundredweight for lambs; (3) the price for the beef alternative for summer grazing of yearling steers, had to be $\$ 25.14$ or above per hundredweight before the alternative appeared in optimum plans with market hogs and sheep; (4) a price of nearly $\$ 31.80$ per hundredweight for feeder pigs was required for the sow-feeder pig alternative to replace sheep in optimum plans; and (5) the dairy alternative completely replaced market hogs and sheep in optimum plans at milk prices of $\$ 3.79$ per hundredweight and above.

\section{CONCLUSIONS}

The selected crop and livestock alternatives considered in this study showed a consistent pattern both of appearing in the optimum plans obtained and in the relative profitability of their utilizing available resources for each of the farm resource situations analyzed. The results of this study also indicate that of the livestock alternatives considered, the most to the least profitable alternative uses for available resources on the study farm situations are: (1) dairy, (2) market hogs, (3) sheep, and (4) beef and other of the selected alternatives. The study also indicates that the present utilization of the available resources on the study farm situations for beef cow-calf production is not as profitable as dairy, market hog, and/or sheep production would be on these farms.

Other important findings were that: (1) crop production, when following the fertilization levels used in this study, was quite profitable, and crop production for cash sale rather than for utilization through livestock appeared profitable, assuming available markets; (2) pastureland was not restrictive and improvement of pastureland was, therefore, relatively unprofitable for all situations analyzed; (3) when there is restricted access to capital and market hog production is excluded, sheep are a profitable livestock alternative; (4) with a 10 per cent reduction in the price used for market hogs or a 10 per cent increase in the price of lambs, sheep would become more profitable, relatively, in utilizing resources available on the study farms; (5) a price of approximately $\$ 31$ per hundredweight for feeder calves would be needed before the beef cow-calf alternative would become relatively more profitable than sheep; (6) prices ranging from $\$ 32.90$ to $\$ 38.90$ per hundredweight for feeder calves would be needed for the beef cow-calf alternative to profitably replace market hogs in these optimum plans; and (7) cropland, livestock building space, capital, and labor are commonly restrictive resources for these sample farm resource situations, and expansion of these resources, in general, would be profitable for farmers in the area comprising the basis for this study. 


\section{BIBLIOGRAPHY}

Agricultural Planning Data for the Northeastern United States. Department of Agricultural Economics and Rural The Pennsylvania State University, 1965.

Alfred et al., Beef Cattle Systems and Range Barr, Alfred L., et al., Beef Cat . Sstimated Production, Improvement Alternatives. Estiment of Agricultural Income, and Costs. Departes P-358. Stillwater: Economics, Processed Series Pember, 1960.

Oklahoma State University, S., and Wilson, C. C.,

Barr, Alfred L., Toben, George E., and Wilson, Eastern Resources, Production and Farms, West Virginia West Virginia Beef Cattleriment Station BulUniversity Agricultural West Virginia University, letin 1967.

Heady, Earl O., and Candler, Wilfred. Linear Programming Methods. Ames, lowa: The lowa State College Press, 1958.

Layton, Ronald A., "Optimum Farm Plans for Utilizing Resources by Selected Alternatives on Eastern West Virginia Livestock Farms." (Unpublished M.S. Thesis, Division of Resource Mant Virginia University, 1970.)

Layton, Ronald A., Barr, Alfred L., and Nesselroad Paul E., Estimated Annual Costs, Production, and Income for Selected Livestock and Virginia Uniprises, Eastern West Virginia, West Virginia University Agricultural Experiment Statio University, June, 1970.
Miller, Allen, Agricultural Stabilization and Conservation Service United States Department of Agricultion Sorgantown, West Virginia. Personal teleture,

Parm Organization for a , Appalachian Plateau, West Virginia Portion of the Appalachion Bulletin University Agriculur West Virginia University, June 593T.

Pohlman G. G. Personal interviews with him as an gronomist, Division of Plant Sciences, West Virgrinia, Noginia Univers through July, 1969.

vember, 1968 through July, 1969.

U. S. Department of Agriculture, Economich, and Statistical Reporting, Agricultural Resk of AgriForeign Agricultural Sricultural Handbook No. 359. Washington: U. S. Government Printing Office, 1968.

U. S. Department of Agriculture, Soil Conservation Service. Soil Survey: Berkeley County, West Virginia. Washington: U. S. Government Printing Office, 1966.

Soil Survey: Monroe County West Virginia. Washington: U. S. Government Printing Office, 1965. County, West Virginia. Washington: U. S. Government Printing Office, 1967. 
APPENDIX TABLE 1. Description of soil series estimated to occur in highest incidence as cropland on study farms in each of the three study areas.

\begin{tabular}{lccc}
\hline \hline Soils & $\begin{array}{c}\text { Study Areas } \\
\text { Located }\end{array}$ & $\begin{array}{c}\text { Land Use } \\
\text { Capability Classes }\end{array}$ & Description \\
\hline Huntington & I & I & $\begin{array}{l}\text { Bottomland; derived from lime uplands; very high } \\
\text { inherent fertility; deep; high moisture; well drained; } \\
\text { moderate to rapid permeability; found with approxi- } \\
\text { mately level topography; and subject to overflow. }\end{array}$
\end{tabular}

Pope

I

II

Monongahela

I, II

II

Litz-Calvin

I

III, IV

Pope-Philo

II

I

Atkins

II

III

Dekalb-Lehew

II

III

Belmont

II

IV

Frankstown-

Frederick-

Pickaway
Bottomland; derived from gray acid shales and sandstones; moderate to high inherent fertility; deep; high moisture; well drained; moderately rapid permeability; found with approximately level topography; and subject to overflow.

Terrace; derived from acid uplands; low inherent fertility; moderately deep; moderate moisture; moderately well drained; slow permeability; found on $0-8$ per cent slopes; found on terraces; and have fragipans.

Upland; derived from weakly alkaline or red acid shales; low to moderate inherent fertility; very shallow to shallow; very low to low moisture; well drained; moderate to rapid permeability; found on 10-30 per cent slopes; and are droughty.

Bottomland; derived from acid shales and sandstones; moderate to high inherent fertility; deep; moderate to high moisture; moderately well to somewhat poorly drained; slow to moderate permeability; found with approximately level topography; and subject to overflow.

Bottomland; derived from acid uplands; low to moderate inherent fertility; deep; high moisture; poorly drained; very slow to slowly permeable; found with approximately level topography; and found in floodplains, and subject to overflow.

Upland; derived from gray or red acid sandstones; low inherent fertility; shallow to moderately deep; low to moderate moisture; well drained; moderate to rapid permeability; found on 5-20 per cent slopes; and stony.

Upland; derived from red and gray shales and interbedded limestones; high inherent fertility; moderately deep; moderate to moderately high moisture; well drained; moderate permeability ; found on 20-30 per cent slopes on sink plateaus; and stony.

Upland; derived from impure limestones; moderate to high inherent fertility; deep; moderate to high moisture; well to moderately well drained; moderate permeability; found on $3-25$ per cent slopes; and associated with upland plateaus.

Map of Wirginia (Beltsville: SCS, USDA, 1958); Boy

Sources: U. S. Department of Agriculture, Soil Conservation Service, Land Resource Map of Worgantown: West Virginia State Office, SCS, 1955), J. Patton, A Brief Description of the Major Soils of West Virginia, USice, Soil Survey: Monroe County: Berkeley County: T u c k e pp. 1-4 and U. S. Department of Agriculture, Soil Conservation Service, Soil Survey 1967, respectively), pp. 113-14, 142-43, and 66, re County, West spectively. 